\title{
Y-Cell Receptive Field and Collicular Projection of Parasol Ganglion Cells in Macaque Monkey Retina
}

\author{
Joanna D. Crook, ${ }^{1,2}$ Beth B. Peterson, ${ }^{1}$ Orin S. Packer, ${ }^{1}$ Farrel R. Robinson, ${ }^{1,3}$ John B. Troy, ${ }^{4}$ and Dennis M. Dacey ${ }^{1,3}$ \\ ${ }^{1}$ Department of Biological Structure, ${ }^{2}$ Graduate Program in Neurobiology and Behavior, and ${ }^{3}$ Washington National Primate Research Center, University of \\ Washington, Seattle, Washington 98195, and ${ }^{4}$ Department of Biomedical Engineering, Northwestern University, Evanston, Illinois 60208
}

The distinctive parasol ganglion cell of the primate retina transmits a transient, spectrally nonopponent signal to the magnocellular layers of the lateral geniculate nucleus. Parasol cells show well-recognized parallels with the $\alpha$-Y cell of other mammals, yet two key $\alpha$-Y cell properties, a collateral projection to the superior colliculus and nonlinear spatial summation, have not been clearly established for parasol cells. Here, we show by retrograde photodynamic staining that parasol cells project to the superior colliculus. Photostained dendritic trees formed characteristic spatial mosaics and afforded unequivocal identification of the parasol cells among diverse collicular-projecting cell types. Loose-patch recordings were used to demonstrate for all parasol cells a distinct Y-cell receptive field "signature" marked by a nonlinear mechanism that responded to contrast-reversing gratings at twice the stimulus temporal frequency [second Fourier harmonic (F2)] independent of stimulus spatial phase. The F2 component showed high contrast gain and temporal sensitivity and appeared to originate from a region coextensive with that of the linear receptive field center. The F2 spatial frequency response peaked well beyond the resolution limit of the linear receptive field center, showing a Gaussian center radius of $\sim 15 \mu \mathrm{m}$. Blocking inner retinal inhibition elevated the F2 response, suggesting that amacrine circuitry does not generate this nonlinearity. Our data are consistent with a pooled-subunit model of the parasol Y-cell receptive field in which summation from an array of transient, partially rectifying cone bipolar cells accounts for both linear and nonlinear components of the receptive field.

Key words: primate; superior colliculus; retina; Y cell; magnocellular; spatial vision

\section{Introduction}

The alpha-Y cells are one of the most intensively studied ganglion populations of mammalian retina yet the identity and functional significance of this pathway in the primate remains, somewhat surprisingly, unresolved. On morphological grounds the parasol ganglion cell type appears the obvious primate alpha-Y cell analog. Like cat alpha cells, parasol cells have the largest cell bodies and thickest axons of any ganglion cell type and comprise two independent cell populations that stratify narrowly near the center of the inner plexiform layer (Watanabe and Rodieck, 1989). Parasol cells like the alpha cells of other mammals are selectively labeled by a neurofibrillar stain (Peichl et al., 1987; Silveira and Perry, 1991), and show a type-specific pattern of tracer-coupling to amacrine cells (Dacey and Brace, 1992; Vaney, 1994; Xin and Bloomfield, 1997; Hu, and Bloomfield, 2003; Schubert et al.,

Received June 27, 2008; revised Sept. 2, 2008; accepted Sept. 7, 2008.

This work was supported by the Paul Kayser International Award from the Retina Research Foundation (D.M.D.), National Institutes of Health Grant EY06678 (D.M.D.), Vision Research Center Grant EY01730, the Tissue Distribution Program of the National Primate Research Center at the University of Washington, Grant RR00166, and National Science Foundation Grant DBI-0551852 (J.B.T.). We thank Julian Vreislander for programming assistance through the Vision Core and the development of the Vision Core Toolbox (http://vrc.biostr.washington.edu/vct/ vct_home.html). We also thank Barry Lee for advice and discussion, Toni Haun for technical assistance, and Anita Hendrickson for comments on this manuscript. We dedicate this paper to Prof. Dr. Heinz Wässle, who first identified cat Y-cells as alpha ganglion cells (Cleland et al., 1975), on the occasion of his retirement.

Correspondence should be addressed to Dennis M. Dacey, Department of Biological Structure, University of Washington, Seattle, WA 98195. E-mail: dmd@u.washington.edu.

DOI:10.1523/JNEUROSCI.2982-08.2008

Copyright $\odot 2008$ Society for Neuroscience $\quad 0270-6474 / 08 / 2811277-15 \$ 15.00 / 0$
2005; Völgyi et al., 2005). Both cat alpha-Y and primate parasol cells project to the large cell relay in the lateral geniculate nucleus (LGN) (Leventhal et al., 1981; Perry and Cowey, 1981; Wässle et al., 1981; Perry et al., 1984). The physiological link between the alpha-Y and magnocellular-parasol pathway has also been long appreciated (Dreher et al., 1976; Sherman et al., 1976; DeMonasterio, 1978; Schiller and Malpeli, 1978). Both cell classes show fast axonal conduction times, large center-surround receptive fields, transient, achromatic light responses and high contrast and temporal sensitivity.

Two uncertainties challenge the parsimonious parasolalpha-Y cell homology. First, it is unclear whether the parasol cells, like the alpha-Y cells, show a projection to the superior colliculus. Antidromic activation (Schiller and Malpeli, 1977; DeMonasterio, 1978) and retrograde tracing (Bunt et al., 1975; Leventhal et al., 1981) experiments concluded that the largestbodied, fastest-conducting cells projected to the superior colliculus. However, other tracing experiments found a parasol projection only to the LGN (Perry and Cowey, 1984; Rodieck and Watanabe, 1993). Second, it is unclear whether parasol cells show nonlinear spatial summation, the sine qua non of the mammalian alpha-Y cell (Enroth-Cugell and Robson, 1966; Demb et al., 1999). Recordings from retina (Crook et al., 1988; White et al., 2002; Solomon et al., 2006; Petrusca et al., 2007) and LGN (Kaplan and Shapley, 1982; Derrington and Lennie, 1984; Blakemore and Vital-Durand, 1986; Spear et al., 1994; Levitt et al., 2001) failed to consistently observe a nonlinear second harmonic 
(F2) or "frequency-doubled" component in the magnocellular pathway spatial frequency response (Hochstein and Shapley, 1976a). Thus, it has been proposed that the parasol cells are, in fact, the primate correlate of the spatially linear beta-X cell (Shapley et al., 1981; Shapley and Perry, 1986), and that the primate alpha-Y cell type awaits discovery (Shapley and Perry, 1986; Petrusca et al., 2007).

In experiments aimed at identifying the central targets of ganglion cell types (Dacey et al., 2003; Dacey, 2004), we found parasol cells consistently labeled from tracer injections into the superior colliculus. These anatomical results, summarized here, prompted us to reexamine spatial nonlinearity in the parasol cell receptive field. We show here that parasol cells consistently display a large spatial phase-independent F2 response and provide evidence that this $\mathrm{F} 2$ response derives from inherently rectifying cone bipolar input to the receptive field center (Demb et al., 2001).

\section{Materials and Methods \\ General approach}

Our strategy to study collicular projections was to place small injections of the retrograde tracer rhodamine dextran into physiologically identified locations in the superior colliculus. The tracer was chosen to permit retrogradely labeled retinal ganglion cells to be intracellularly stained by a photodynamic reaction elicited by brief exposure of the retina to epifluorescent illumination after the retina was dissected and placed in vitro (Dacey et al., 2003). Histological processing of serial sections through the brainstem after tissue fixation was used to characterize the location and extent of the tracer injections in each animal.

\section{Tracer injections}

Experiments were performed on seven adult macaque monkeys (Macaca mulatta). All procedures involving primates were approved by the Institutional Animal Care and Use Committee at the University of Washington and conform to the Public Health Service Policy on Humane Care and Use of Laboratory Animals. Animals were anesthetized with isoflurane $(1.0-2.0 \%)$ and prepared for recording in an aseptic surgery by positioning the head in a stereotaxic device. A small craniotomy was made over the stereotaxic center location of the superior colliculus. Eyelids were held open and corneas kept moist with applications of ophthalmic ointment. The position of the superior colliculus was determined by recording multiunit activity in response to repetitive flashes of white light (10 $\mu$ s full-field flashes at $1 \mathrm{~Hz}$; Grass photic stimulator; PS33R) with either an epoxy-coated etched tungsten electrode or a modified injection pipette. The rostral, caudal, medial, and lateral borders of the superior colliculus were plotted onto stereotaxic maps of the superior colliculus. Injection solutions were $10 \%$ biotinylated dextran-conjugated tetramethylrhodamine $3000 \mathrm{mw}$ (microruby, D-7162; Invitrogen) in distilled water or sterile saline. A total volume of $0.25 \mu \mathrm{l}$ of tracer was used for each injection tract. The superior colliculus usually received more than one injection, with the injections spaced $0.5-1 \mathrm{~mm}$ apart. In most instances, tracer injections were made while simultaneously recording visually evoked activity in the retinorecipient collicular layers via the injection pipette to help accurately localize injection tracks. After postoperative recovery and a survival time of $4-7 \mathrm{~d}$, the animal was deeply anesthetized with barbiturate; the eyes removed, and the animal was perfused through the heart with $800 \mathrm{ml}$ of warm $37^{\circ} \mathrm{C}$ normal saline followed immediately by 41 of $4^{\circ} \mathrm{C} 4 \%$ paraformaldehyde. The animal was then perfused with 1 L each of 10, 20, and 30\% sucrose solutions. Frozen sections of the brain were cut and treated to reveal tracer locations by HRP histochemistry as described below for retina processing.

\section{Retinal preparation}

The in vitro whole-mount retina preparation has been described previously (Dacey and Lee, 1994; Dacey et al., 1996). In brief, after enucleation the retina was dissected free of the vitreous and sclera in oxygenated Ames' Medium (Sigma), and the retina-retinal pigment epithelium (RPE)-choroid was placed flat, vitreal surface up, in a superfusion cham- ber mounted on the stage of a light microscope. Ganglion cells retrogradely labeled with rhodamine-dextran were visualized under epiillumination with a green filter block (excitation filter, $545 \mathrm{~nm}$; barrier filter, $590 \mathrm{~nm}$ ) and targeted for retrograde photostaining using a $40 \times$ water-immersion objective. Retrogradely labeled ganglion cells were photostained by brief exposure $(\sim 10 \mathrm{~s})$ to epifluorescent illumination $\left(7.5 \times 10^{13}\right.$ photons $/ \mu \mathrm{m}^{2} / \mathrm{s}$ measured at the retinal surface using a spectrophotometer, $20 \times$ objective, $100 \mathrm{~W}$ mercury vapor lamp, and green filter block) that triggered a breakdown of the punctate fluorescent granules localized to the cell body followed by a rapid diffusion of the fluorophore throughout the dendritic tree and a marked increase in the fluorescence intensity (for further discussion of this methodology, see Dacey et al., 2003). At low magnification, groups of neighboring cells were stained simultaneously while monitoring the photodynamic process microscopically. Usually only a brief exposure was needed to initiate photostaining, which then continued without further illumination.

\section{Histology}

After a collicular injection experiment and after photostaining, retinas were dissected free of the RPE and choroid, fixed for $2 \mathrm{~h}$ in $4 \%$ paraformaldehyde, and rinsed overnight in phosphate buffer $(0.1 \mathrm{~m}, \mathrm{pH} 7.4)$. Retinas were incubated in $0.1 \%$ Triton X-100, $\mathrm{pH} 7.4$, containing the Vector avidin-biotin-HRP complex (Elite kit; Vector Laboratories) for $8 \mathrm{~h}$, rinsed in phosphate buffer overnight, and processed for HRP histochemistry using diaminobenzidine (DAB) as the chromogen. Retinas were incubated in the DAB solution $(0.1 \%$ in $0.01 \mathrm{M}$ phosphate buffer, $\mathrm{pH}$ 7.4) for $5 \mathrm{~min} ; \mathrm{H}_{2} \mathrm{O}_{2}(0.03 \%)$ was then added and the retinas were further incubated for 3-4 min followed by an overnight rinse in phosphate buffer. Retinas were whole mounted without dehydration on slides with polyvinyl alcohol, coverslipped, and stored refrigerated.

Lightly stained cells were photochemically enhanced using $0.02 \%$ ni-

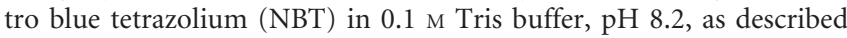
previously (Vaney, 1992). In some retinas, we alternatively improved photostaining by an additional immunohistochemical step using biotinylated anti-rhodamine before HRP processing. After fixation, retinas were incubated in $0.1 \%$ Triton X-100 in PBS $(0.1 \mathrm{M}, \mathrm{pH} 7.4)$ containing biotinylated anti-rhodamine (BA-0605; Vector Laboratories) at a concentration of 1:100 for $36 \mathrm{~h}$ at room temperature, then washed in phosphate buffer overnight. Retinas were then processed for HRP histochemistry as described above using the Vector avidin-biotin-HRP complex and DAB. This method had the advantage of producing darkly stained cells without the lengthy washing required to remove unreacted NBT from the tissue.

To locate the injection sites, brain sections ( $50 \mu \mathrm{m}$ thick) were reacted to reveal biotin labeling using the same HRP histochemistry as described above, except that free floating sections were incubated in the $0.1 \%$ Triton X-100/avidin-biotin-HRP solution for $2.5 \mathrm{~h}$, and then washed in phosphate buffer for $2 \mathrm{~h}$, changing the buffer every $20 \mathrm{~min}$. DAB reaction and slide mounting were the same as described above.

\section{Loose-patch recordings}

Tissue preparation and electrical recording. Nonretrogradely labeled tissue from either Macaca nemestrina, Macaca fascicularis, or Papio anubis retinas were prepared as described above and previously (Dacey and Lee, 1994; Dacey et al., 1996). Parasol ganglion cells were selectively targeted by their distinctive cell body shape and large size under infrareddifferential interference contrast (IR-DIC) optics. Loose cell-attached extracellular voltage-clamp recordings (voltage clamp set to $0 \mathrm{mV}$ ) were made with glass microelectrodes $(\sim 5 \mathrm{M} \Omega)$ filled with Ames medium or a solution containing (in mM) $125 \mathrm{~K}$-DL-aspartate, $1 \mathrm{Mg}-\mathrm{Cl}_{2}, 10 \mathrm{KCl}, 10$ HEPES, $5 \mathrm{~N}$-methyl-D-glucamine, $0.5 \mathrm{CaCl}_{2}, 4 \mathrm{Mg}$-ATP, and 0.5 TrisGTP, with $\mathrm{pH}$ adjusted to 7.2 with $\mathrm{Cs}-\mathrm{OH}$ and osmolarity approximately $280 \mathrm{mOsm}$. No differences were found in the quality or character of the extracellular recordings using either Ames or K-based electrode filling solutions.

Data acquisition. Responses to stimuli were amplified (Axopatch 200B; Molecular Devices), digitized at a sampling rate of $5 \mathrm{kHz}$, and averaged over multiple stimulus cycles (ranging from 2 to 150, depending on stimulus temporal frequency). The first (F1) and second fundamental 


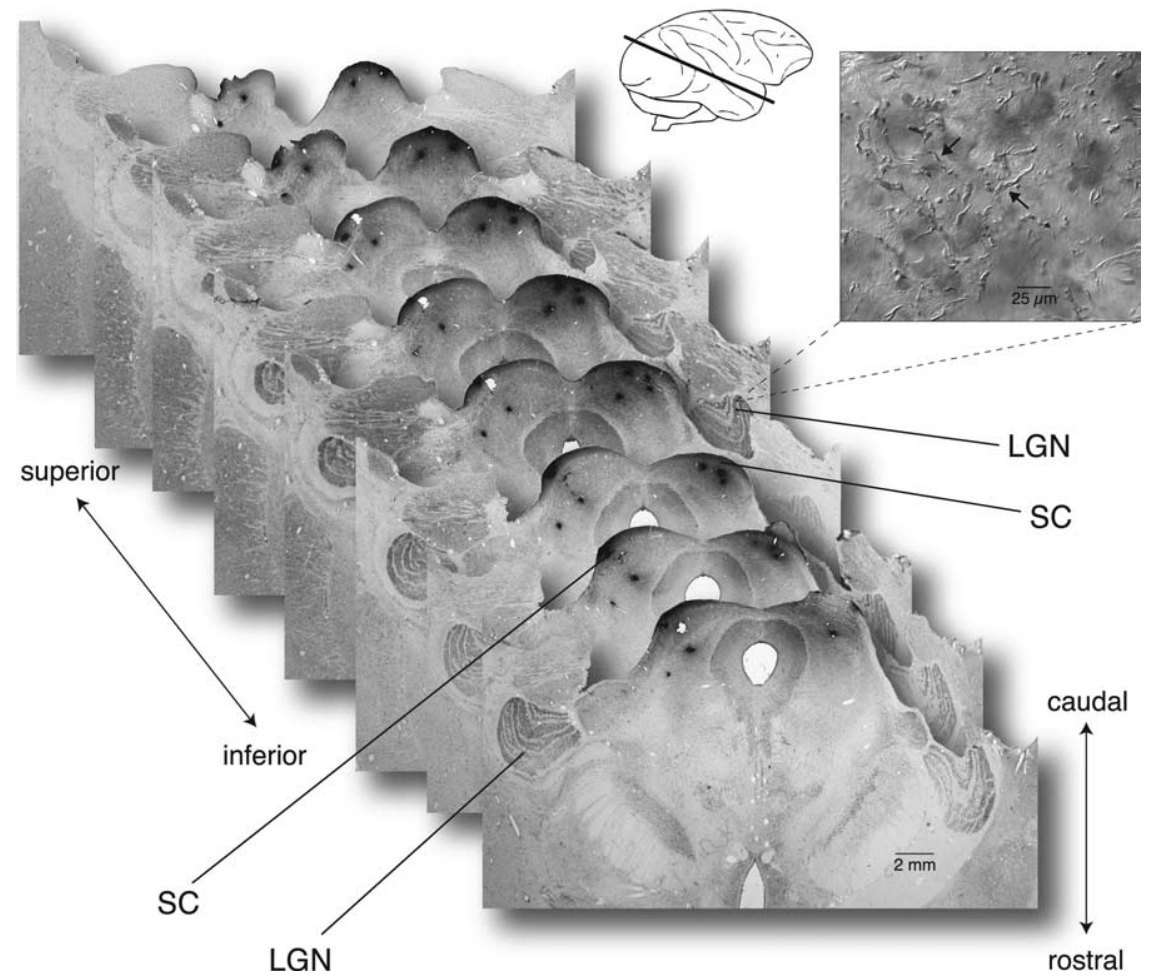

Figure 1. Photomicrographs of macaque brain sections showing injection of biotinylated rhodamine dextran confined to the superior colliculus (SC). Sections are shown stacked consecutively from bottom right to top left covering $\sim 1.2 \mathrm{~mm}$ distance. Orientation of stacked sections is from inferior (bottom right) to superior (top left); orientation of individual sections is from rostral (bottom edge of section) to caudal (top edge). Inset at top right shows a drawing of macaque brain with the plane of sectioning indicated by the black line. Inset micrograph at right illustrates distinct terminal labeling observed surrounding the cell bodies of neurons within the magnocellular LGN layers, presumably originating from axon collaterals of ganglion cells retrogradely labeled by tracer injections made in the superior colliculus.

(F2) amplitudes and phases of the response spike were calculated at the fundamental temporal frequency of the stimulus using a digital Fourier transform. F2 values were only used if there was clear evidence of frequency doubling in the histograms and if the calculated F2 was greater than the calculated F1. Spikes were detected with a simple threshold test. Before the start of each stimulus, a baseline was recorded by averaging the electrode current values in a block of 10 consecutive $10 \mathrm{~ms}$ samples. A spike time stamp was recorded when a sample was recorded with a current exceeding a user-adjustable threshold increment above baseline and appropriate for the prevailing spike amplitudes and noise conditions. This threshold test detects a point on the leading edge of a spike with a 1.2 ms dead time before detecting the next spike, to prevent double counting.

Visual stimuli. Stimuli with spatial structure (spots, annuli, gratings) were generated by a three-primary (peak wavelengths, 460, 558 and 648 $\mathrm{nm}$ ) digital light projector (DLP) (VistaGRAPHX 2500; Christie Digital) driven at a frame rate of $63 \mathrm{~Hz}$ by a VSG Series 5 video stimulus generator (Cambridge Research) using custom software (http://vrc.biostr.washington.edu/vct/vct_home.html). The application of DLP technology to generate visual stimuli for neurophysiological experiments has been described in detail previously (Packer et al., 2001). Full-field stimuli used for measuring temporal responsivity and chromatic tuning were created using a four-primary light-emitting diode (LED)-based stimulator (Swanson et al., 1987; Pokorny et al., 2004) whose dominant wavelengths were $460,512,560$, and $658 \mathrm{~nm}$. Stimuli were delivered to the camera port of the microscope via relay optics and brought into focus on the retinal surface with either a $4 \times$ or $10 \times$ objective producing a rectangular stimulus field of $2.9 \times 2.2 \mathrm{~mm}$ or $1.2 \times 0.9 \mathrm{~mm}$, respectively. The effective number of photons per second per square micrometer at the wavelength of maximal sensitivity for the long- (L), middle- (M), and shortwavelength-sensitive $(S)$ cones were calculated from the spectra of the primary channels of the DLP and LED stimulators, and the spectral sensitivities were measured for macaque cones in vitro (Baylor et al.,
1987). For all achromatic stimuli, all three DLP channels were turned on to full intensity and attenuated by neutral density filters to produce a high-photopic white stimulus. Mean effective photons for the $\mathrm{L}, \mathrm{M}$, and $\mathrm{S}$ cones were, respectively, $6.15 \times 10^{4}, 4.35 \times 10^{4}$, and $7 \times 10^{3}$ photons $/ \mathrm{s} / \mu \mathrm{m}^{2}$.

The stimulus was centered on the receptive field by determining the location of peak sensitivity to bars $10-25 \mu \mathrm{m}$ in width sequentially positioned across the receptive field center. To quickly assess response dynamics and center and surround responsiveness, we initially probed the receptive field with complimentary spot and annular stimuli (500 ms pulses on a dark background) of varying diameters.

To investigate linear components of the parasol cells receptive field (first harmonic; F1), drifting sinusoidally modulated gratings of varying spatial and temporal frequencies $(0.61-31 \mathrm{~Hz})$ were presented at a range of contrasts to determine receptive field size and contrast and temporal sensitivities. Nonlinear receptive field component properties (second harmonic; F2) were similarly investigated using stationary contrast-reversing gratings. To investigate spatial phase sensitivity, contrastreversing gratings were systematically shifted in spatial phase in $45^{\circ}$ intervals relative to the receptive field midpoint of the cell. In an attempt to isolate nonlinear center and surround receptive field components, contrast-reversing gratings were also isolated in spots and annuli of varying diameter. Spatial stimuli were modulated at $50 \%$ contrast $\left(L_{\mathrm{MAX}}-L_{\mathrm{MIN}}\right) /$ $\left(L_{\mathrm{MAX}}+L_{\mathrm{MIN}}\right)$ for gratings, spots, and annuli. For response versus contrast functions, contrast was increased incrementally: 3.125 , $6.25,12.5,25,50,75$, and $100 \%$.

Analysis. Spatial tuning curves derived from drifting grating stimuli were fit using a difference of Gaussians model (DoG) of the receptive field that incorporates both the amplitude and phase of the neural response (Enroth-Cugell et al., 1983). Details and application of this model have been described previously (Dacey et al., 2000; McMahon et al., 2004). In brief, response amplitudes and phases were used to determine the parameters of the model. There are six free parameters: the amplitude, radius, and phase of the center and surround Gaussians. The strengths of center and surround mechanisms are defined by the integrated volumes of their best-fitting Gaussians. Automated numerical search coupled with a user-controlled iterative fitting procedure was used to find the model parameters that provided the best fit to the data. The mean square difference between the model prediction and measured response gave an error function that was minimized during the fitting procedure. The high-spatial-frequency limb of spatial frequency tuning curves for the F2 created from contrast-reversing gratings was fit with a Gaussian receptive field model. As for the case of the DoG fit to the F1 data, a numerical search was made that minimized the mean square error between data and model.

We defined the receptive field diameter as three times the DoGcalculated Gaussian radius. This definition is arbitrary, but has been shown to be associated with maximum responsivity and minimum threshold for the receptive field center and to most closely match the dendritic field diameter of the recorded ganglion cell; it has been referred to as the "full center" (Peichl and Wässle, 1979, 1983; Lee, 1999). Subsequently full-center receptive field diameter measurements were used to calculate the spatial frequency resolution limits of the cells. At the spatial frequency resolution limit of the cell, three sinusoidal cycles are expected to fit into the full-center receptive field diameter (Crook et al., 1988; Lee, 1999). 
Contrast-response functions for the F1 and F2 were fit with a Naka-Rushton saturation function: $Y=a \mathrm{x} /(b+x)$, where $a$ is the maximal response in impulses per second, $x$ is the Michelson contrast, and $b$ is the semisaturation constant (the contrast at which response amplitude is half the maximal response). Such curves are characterized by their percentage contrast gain, which can be determined either by using the fits to calculate $a / b$, or by fitting the linear, low-contrast portion of the response-contrast function of each cell with a least-squares bestfitting straight line. The slope of this line is the contrast gain of the cell (slope/100). We calculated the contrast gain using both methods and they correlated well, although values calculated as $a / b$ were larger. We present values calculated by the maximal response divided by the semisaturation contrast $(a / b)$ in Results so they can be compared with previous work.

Pharmacology. To assess the general role of inhibitory synaptic drive on the nonlinear response component, we bath applied a solution containing $200 \mu \mathrm{M} \mathrm{GABA}_{\mathrm{A} / \mathrm{C}}$ receptor antagonist picrotoxin (P1675-1G; Sigma) and $1 \mu \mathrm{M}$ glycine receptor antagonist strychnine (S8753; Sigma). The drugs were perfused together with oxygenated Ames' solution onto the retina. We typically waited $\sim 5 \mathrm{~min}$ before recording lightevoked responses after blockade of inhibition, and recorded for $\sim 30 \mathrm{~min}$ before solution wash out and additional recording.

\section{Results}

\section{Collicular tracer injections}

Tracer injections of rhodamine dextran were made into both the left and right superior colliculi in seven animals. After mapping the borders of the colliculus by monitoring multiunit activity to repeated light flashes, $250 \mathrm{nl}$ injections were made in the caudal half of each colliculus. We confirmed the location examining serial sections through the brainstem from the optic chiasm anteriorly to the posterior pole of the colliculus caudally. Alternate sections were processed for HRP histochemistry and cresyl violet staining, and injection tracts and labeling patterns were surveyed. Our goal was to confirm that the injections were confined to the colliculus and that the retinorecipient pretectal area rostral to the colliculus and the LGN were free of tracer. In all data used in this study, injection tracts were confined to the colliculus (Fig. 1), although some tracks extended ventral to the superficial layers and terminated in the deep collicular layers and underlying reticular formation. No cellular labeling or tracer deposits were found in the LGN; indeed, LGN histology was beautifully preserved and we thus made an effort to find evidence for retrogradely labeled axon terminals that would arise via collaterals of collicular-projecting ganglion cells.

In some well-stained cases, distinct terminal arbor morphology around the magnocellular relay cell bodies was occasionally observed (Fig. 1, inset). Some terminals were of very fine caliber, whereas others were of larger diameter, bearing large, distinctive terminal boutons. The origin of this labeling is unknown and no attempt is made here at a quantitative analysis or morphological reconstruction of the terminals; however, given the results to follow, it is possible that at least some of these terminals in the LGN may be axon collaterals of collicular-projecting parasol ganglion cells.

\section{Parasol ganglion cells project to the superior colliculus}

Survival times of 4-5 d gave rise to strong retrograde labeling of ganglion cell cytoplasm. Moderate light exposure for several seconds using the epi-illuminator induced the punctate rhodamine fluorescence to "burst" and spread throughout the dendritic tree resulting in a bright intracellular fill, similar to that observed after intracellular tracer injection (Dacey et al., 2003). By using biotinylated rhodamine dextran, we were able to perform HRP histochemistry after tissue fixation and convert the intracellular rhodamine fluorescence to a permanent HRP reaction product. As expected from previous studies, a number of morphologically distinct ganglion cell types were evident at low magnification (Fig. 2, arrowheads). The large cell bodies and characteristic dendritic morphology of the parasol ganglion cell type (Fig. 2, arrows) were observed in all 12 retinas that contained retrograde labeling after collicular tracer injections (12 of 13 retinas). Intracellular photodynamic staining of the parasol dendritic tree and axon was complete and identical to that seen previously with intracellular injection of HRP or neurobiotin made into the cell body (Watanabe and Rodieck, 1989; Dacey and Brace, 1992) (Fig. 3 ). The narrow band of dendritic stratification near the center of the inner plexiform layer and inner and outer stratifying cell pairs, as well as the relationship of dendritic field size to retinal eccentricity, also confirmed the identification of these large bodied ganglion cells as parasol cells.

It has been suggested that retrograde labeling of parasol cells from the superior colliculus may reflect only a minor projection from a small subset of errant parasol cells (Perry and Cowey, 1984; Rodieck and Watanabe, 1993). However, we found many examples in regions of well photostained cells that contained 
complete or nearly complete spatial arrays of neighboring parasol cells (Fig. $4 A-C$ ). Clusters of 2-10 neighboring cells with dendritic field diameters and overlap characteristic of the parasol cell inner and outer stratifying populations (Dacey and Brace, 1992) were typical in localized patches of retrograde label. We conclude that as a population, the parasol cells project via a branching axon to both the LGN and the superior colliculus.

\section{Selective targeting of parasol cells in vitro}

Parasol cells were selectively targeted for cell-attached extracellular recordings by distinctive cell body shape and large size observed in vitro by IR-DIC optics. In previous anatomical studies, it was found that both inner-ON center and outer-OFF center parasol cells could be targeted with virtually $100 \%$ accuracy using soma size and shape to guide cell choice for intracellular penetration (Watanabe and Rodieck, 1989; Dacey and Brace, 1992; Dacey and Petersen, 1992; Dacey and Lee, 1994; Diller et al., 2004; McMahon et al., 2004). We also confirmed parasol cell identity by observation of characteristic maintained discharge rates, relatively phasic responses to full field stimuli, summation of $\mathrm{L}$ and $\mathrm{M}$ cone input, center-surround organization, and temporal and contrast sensitivity, all properties that have been well documented for this cell population (Kaplan and Shapley, 1986; Benardete et al., 1992; Croner and Kaplan, 1995; Benardete and Kaplan, 1999; Passaglia et al., 2002). The strong correspondence between receptive field center and dendritic field sizes reported later is also consistent with a pure sample of parasol cells. The following results derive from recordings of 113 parasol cells ( 70 ON center and 43 OFF center). All parasol cells had transient responses to light pulses. Maintained spike rates for parasol cells in vitro were variable, but the majority of cells from which data were gathered showed initial maintained rates to a mean background between 20 and 50 spikes/s (31.01 \pm 20.53 spikes/s; mean \pm $\mathrm{SD} ; n=14)$. This is similar to what is found in recordings from the intact animal (Troy and Lee, 1994).

\section{Classification and terminology}

Before considering the physiological results, we briefly clarify our use of the term "Y cell" (for a more detailed consideration of this issue, see Rodieck and Brening, 1983). The early literature on the cat retinogeniculate pathway was dominated by the tripartite X-, Y-, and W-cell physiological classification (for a detailed historical review and an alternative classification scheme, see Cleland and Levick, 1974; Stone, 1983). Y cells were distinguished from X presumed $0 \mathrm{~N}$-center cells.
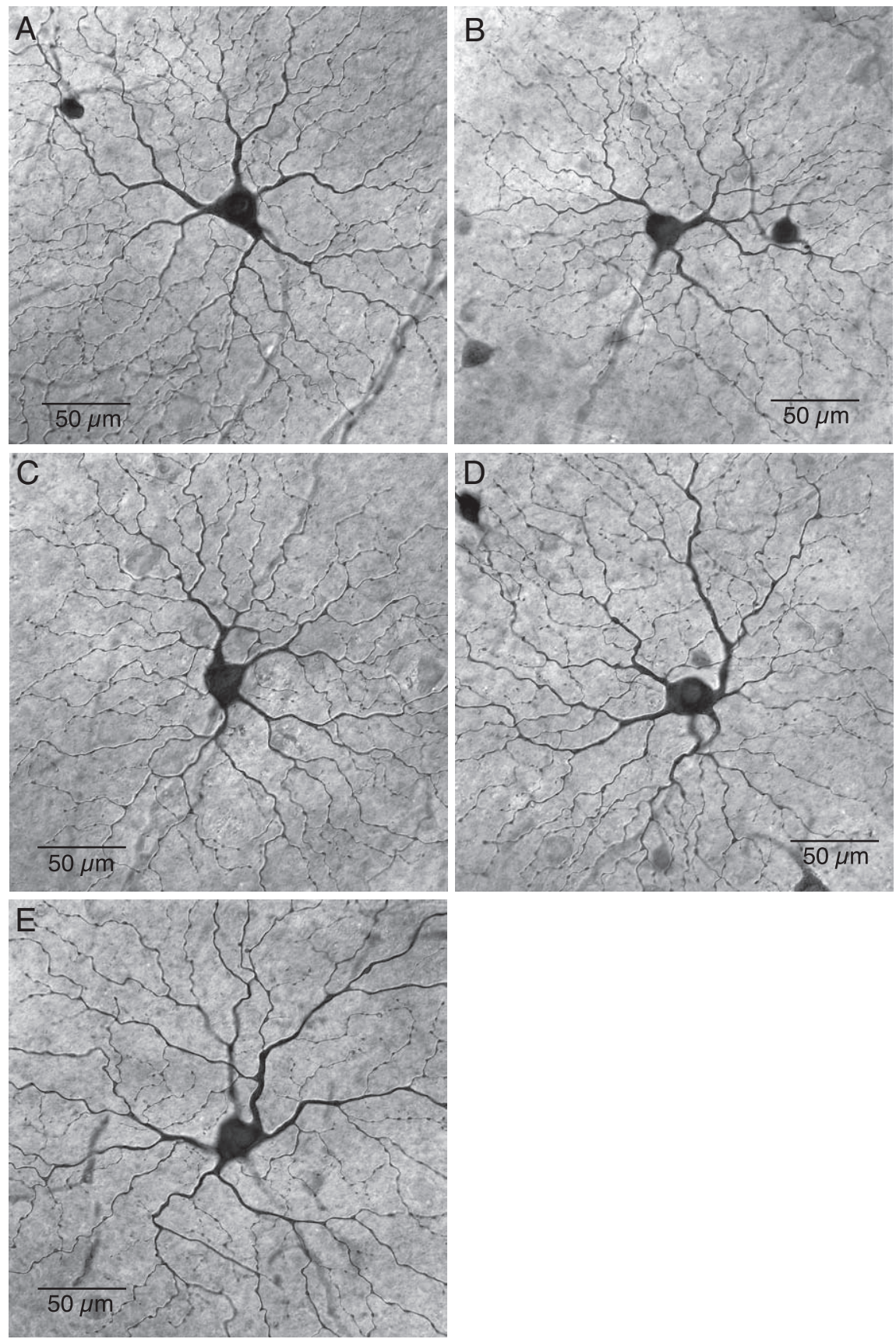

Figure 3. Parasol cells project to the superior colliculus. $A-E$, Photomicrographs of parasol cells from the retinal periphery (eccentricity range, $10-11.5 \mathrm{~mm}$ ) retrogradely labeled by injection of biotinylated rhodamine-dextran into the superior colliculus and photostained in vitro by light exposure. After tissue fixation, the spread of biotinylated rhodamine within the dendritic tree was demonstrated by HRP histochemistry (see Materials and Methods). Parasol cells show an easily identifiable large soma size, thick axon, and narrowly monostratified, radiately branching dendritic tree. Parasol cells shown in $\boldsymbol{A}-\boldsymbol{E}$ are all inner branching,

cells by their phasic responses, large receptive fields, fast axonal conduction velocities, and the property of nonlinear spatial summation. In the cat, such Y cells were subsequently identified as a distinctive anatomical class of retinal ganglion cell, the alpha cells, possessing a characteristic and identifying cluster of morphological and physiological properties (Cleland and Levick, 1974; Cleland et al., 1975; Peichl and Wässle, 1981). However, it is now well documented that the specific property of nonlinear spatial summation is not unique to the alpha-Y ganglion cell type, but is also a property of many of the diverse ganglion cell types 
originally placed in the $\mathrm{W}$-cell grouping (Troy et al., 1995; Isayama et al., 2000). A problem of terminology is thus highlighted: the use of "Y cell" and "Y-cell signature" has served both to indicate a single physiological property (nonlinear spatial summation) and also to identify a single ganglion cell class (using the $\mathrm{X}, \mathrm{Y}, \mathrm{W}$ scheme, a W-Y cell cannot, by definition, exist and therefore has led to the use of terminology such as "nonlinear W cell") (Spear et al., 1989). Here, and in the companion study (Crook et al., 2008), we recognize the dual usage of this term and use it in both senses. We use "Y-cell signature" to refer to a specific characterization of the property of nonlinear summation in a plot of the spatial frequency response of a cell. However, we also will make the argument that the parasol cells are the analog of the cat alpha-Y cells, and more generally the mammalian alpha cell, because parasol cells share a characteristic cluster of anatomical and physiological properties. Similarly in the companion study (Crook et al., 2008), we show that a second, morphologically distinct ganglion cell class, the "smooth" cells, also display nonlinear spatial summation. We then suggest that because the smooth cells share a number of fundamental properties with the parasol-Y pathway (transient, achromatic response, high spike-discharge rates, high temporal and contrast sensitivity, concentric center-surround receptive fields, central projections, dendritic morphology), this newly identified primate ganglion cell class may provide an additional, parallel Y-like pathway, similar to that of the parasol/alpha cell but differing in spatial scale. At the same time, we recognize that other ganglion cell types (e.g., the melanopsinexpressing ganglion cells (Dacey et al., 2005) may show nonlinear spatial summation but share few other properties with the parasol/alpha cell, and it would not be useful to think about the melanopsin cells as a "Y-cell pathway."

\section{Y-cell signature for parasol cells}

A succinct picture of the spatial nonlinearity characteristic of the mammalian alpha-Y cell is captured in what has been called the Y-cell signature (So and Shapley, 1981; Spitzer and Hochstein, 1985; Shapley and Perry, 1986). The Y-cell signature appears in a plot of the spatial frequency response of the linear F1 response at the stimulus temporal frequency to a drifting grating and a distinctive F2 response to counterphase modulation of a stationary grating. This plot illustrates the higher spatial resolution for the F2 compared with the F1 response component. In a typical cat alpha-Y cell, the F2 component has a resolution at least approximately three to five times that of the F1 component (Enroth-Cugell and Freeman, 1987). In this study, all 113 identified parasol cells
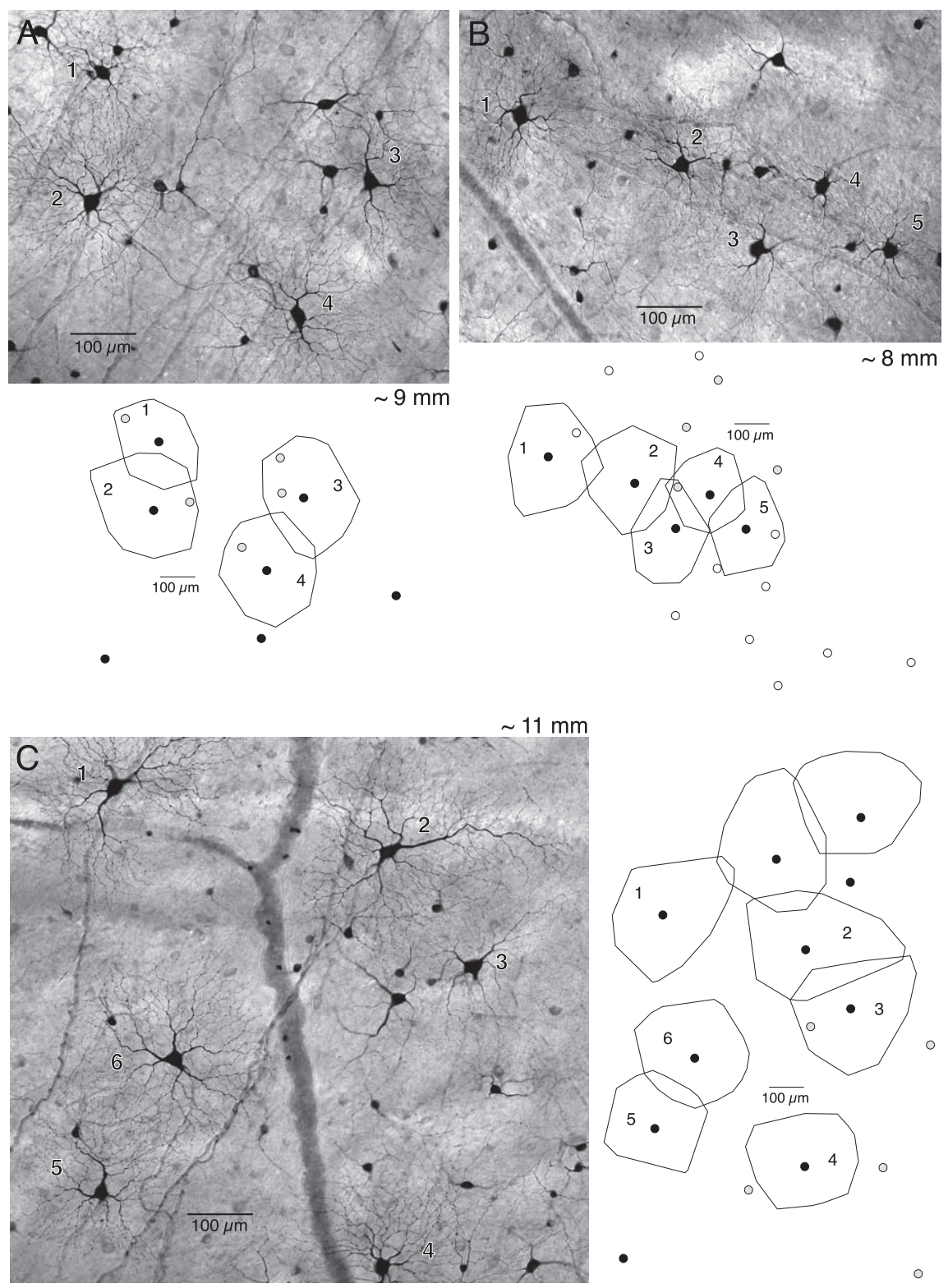

Figure 4. Mosaic of neighboring parasol cells retrogradely stained from injections of biotinylated rhodamine dextran injections into the superior colliculus. $\boldsymbol{A}$, Photomicrograph of two pairs of inner parasol cells with overlapping dendritic fields, at an eccentricity of $\sim 9 \mathrm{~mm}$. Outlines of the dendritic trees of cells labeled $1-4$ are shown below. Black circles show the location of inner stratifying parasol cell somas and gray circles show the location of lightly stained outer parasol cell somas. B, Photomicrograph of five neighboring inner parasol cells with overlapping dendritic fields at an eccentricity of $\sim 8 \mathrm{~mm}$. Outlines of the dendritic trees of cells labeled $1-5$ are shown below. Black and gray circles are as described in $A$; open circles indicate parasol cells that were tracer labeled but too lightly photostained to determine stratification. $C$, Photomicrograph of neighboring inner parasol cells with overlapping dendritic fields at an eccentricity of $\sim 11 \mathrm{~mm}$. Outlines of the dendritic trees of cells labeled $1-6$ are shown below. Outlines of two more fully stained inner parasol cells lying above cell 2 (data not shown in photo) are also shown. Black and gray circles are as described in $\boldsymbol{A}$.

showed a Y-cell signature characterized by a large, bandpass F2 spatial frequency response to contrast-reversing gratings that peaked at high spatial frequencies and was well separated from the F1 component. An example of a Y-cell signature for one macaque ON parasol cell from midperipheral retina (Fig. $5 A$ ) illustrates the spatial frequency roll-off in response to a drifting grating ( $4 \mathrm{~Hz}, 50 \%$ contrast) for the F1 component between $\sim 1$ and 5 cycles per degree (cpd), and the considerably higher roll-off in response to counterphased grating modulation $(4 \mathrm{~Hz}, 50 \%$ contrast) for the F2 component between 10 and $15 \mathrm{cpd}$. The intersection of the F1 and F2 spatial frequency tuning curves is a 


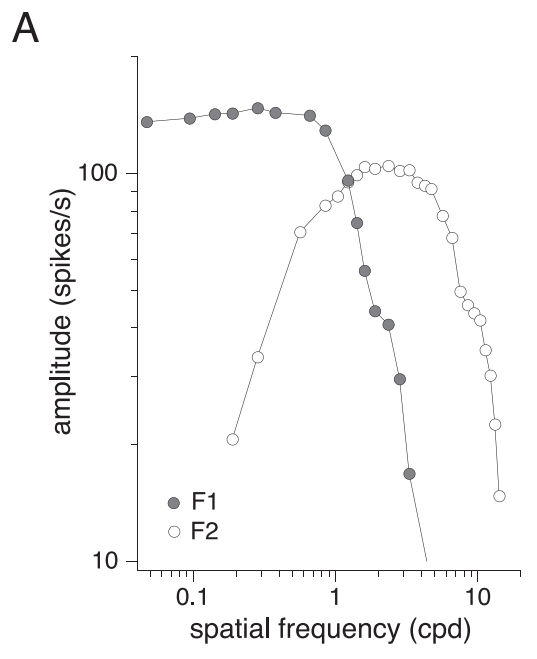

C

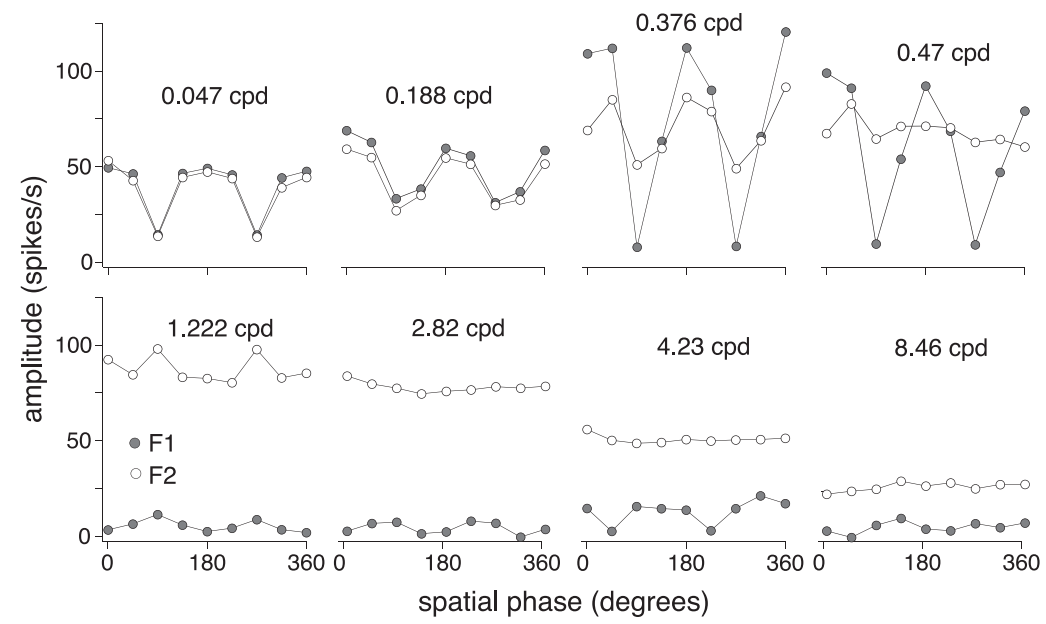

B
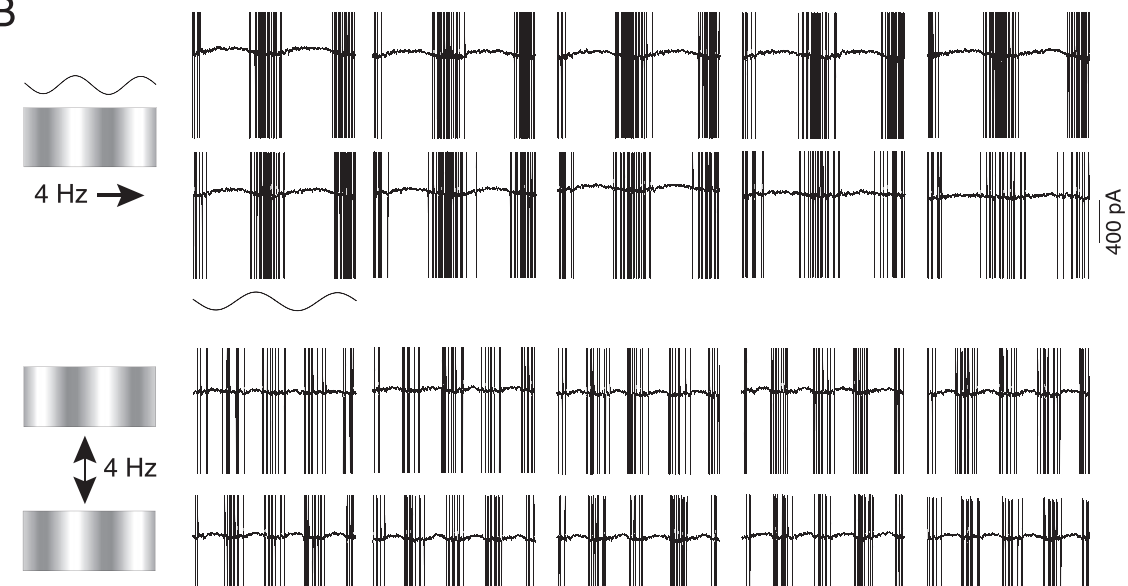

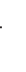
HWHHHH|H|H|H|H|H|H|

D

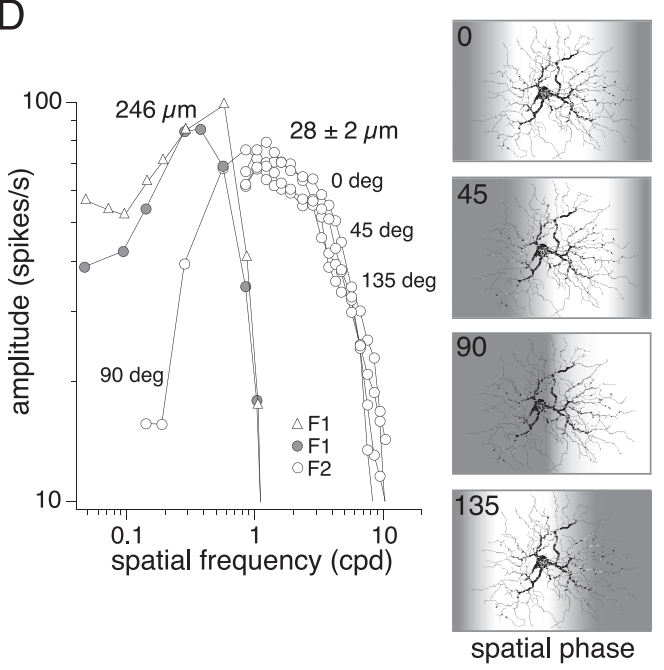

Figure 5. Parasol cells have Y-cell physiology. A, First Fourier harmonic (F1; solid gray circles) responses to drifting sine wave gratings ( $4 \mathrm{~Hz}, 50 \%$ contrast) and second Fourier harmonic ( $F 2$; open circles) responses to stationary contrast-reversing grating ( $4 \mathrm{~Hz}, 50 \%$ contrast) as a function of spatial frequency. The $\mathrm{F} 2$ response curve crosses the $\mathrm{F} 1$ response curve at high spatial frequencies; this is the Y-cell signature. $\boldsymbol{B}$, From the same parasol cell, multiple responses to two cycles of the same stimuli described in $\boldsymbol{A}$ (stimuli trace below). The spatial frequency of the stimulus increases incrementally from left to right ranging from 0.047 to $1.222 \mathrm{cpd}$ for the drifting gratings (top traces) and $0.564-4.23 \mathrm{cpd}$ for the contrast-reversing gratings (bottom traces). Responses to the contrast-reversing grating are at twice the frequency of the stimulus. C, F1 and F2 responses to contrast-reversing gratings of a specific spatial frequency as a function of stimulus spatial phase (degrees). At high spatial frequencies, the F1 is minimal and the F2 dominates and is insensitive to the location of the stimulus. $D$, Parasol $Y$-cell signature as described in $A$, with additional $F 2$ (open circles) responses measured with the stimulus phase at $0,45,90$, and $135^{\circ}$ relative to the receptive field midpoint of the cell, as illustrated to the right in $\boldsymbol{D}$. F2 values (open circles) when greater than the $\mathrm{F} 1$ at a given spatial frequency are plotted. At spatial frequencies greater than the spatial frequency resolution limit of the F1, $\mathrm{F} 2$ responses, regardless of spatial phase, dominate and map out matching spatial frequency tuning curves. The F1 and F2 (mean \pm SD) full-center receptive field diameters are included (see Fig. 6). In addition, F1 responses (open triangles) to counterphase gratings at $0^{\circ}$ phase are plotted to illustrate that the $\mathrm{F} 1$ receptive field could be similarly mapped with either contrast reversing or stationary gratings.

characteristic Y-cell property. Waveforms from the same ONcenter parasol cell shown in Figure $5 B$ illustrate how the F1 component reflects the response to a single position of a drifting grating cycle, when the light bar passes over the center, whereas the F2 component reflects two responses to one cycle of a contrast-reversing grating. Note that the F1 receptive field map was similar whether calculated using F1 responses to contrastreversing or drifting gratings (Fig. $5 D$ ). We use drifting gratings throughout.

The second harmonic response is invariant with spatial phase A critical property of the Y-cell F2 response component is its invariance with stimulus spatial phase at high spatial frequencies. All parasol cells recorded showed such spatial phase invariance of the $\mathrm{F} 2$ response. We illustrate this property in two ways for two additional parasol cells in Figure 5, $C$ and D. Plots of F1 and F2 response amplitude at a range of spatial frequencies shifted in $45^{\circ}$ increments using a contrast-reversing grating (Fig. 5C) illustrate that at low spatial frequencies (0.047$0.376 \mathrm{cpd}$ ) both F1 and F2 components modulate with spatial phase with response minima at $90^{\circ}$ when the stimulus is perfectly centered on the cells receptive field. At higher spatial frequencies $(2.82-8.46 \mathrm{cpd})$, the $\mathrm{F} 1$ component is lost and the response is dominated by a phase-invariant F2 response. Alternatively, we plotted the $\mathrm{F} 1$ responses to drifting gratings (Fig. 5A) and F2 responses to contrast-reversing gratings as a function of spatial frequency at $0,45,90$, and $135^{\circ}$ relative to the receptive field midpoint of the cell (Fig. $5 D$, open circles). At spatial frequencies greater than the resolution limit of the F1, F2 responses independent of spatial phase dominate and trace out identical spatial frequency tuning curves. Thus, both the Y-cell signature of the high-spatial-frequency resolution of 
the F2 compared with the F1 component, and the spatial phase invariance of the $\mathrm{F} 2$ response, are captured in the family of spatial tuning curves shown in Figure $5 D$. Note that in Figure $5 D$ at low spatial frequencies, an F2 response was only measured when the contrastreversing grating was perfectly centered on the cell $\left(90^{\circ}\right)$.

\section{Spatial tuning of the first and second harmonic response components}

In the cat alpha-Y-cell receptive field, the F2 component is modeled as an array of nonlinear subunits, smaller in diameter than the receptive field center. To characterize the relative spatial dimensions of the F1 and F2 components for the macaque parasol cells, we fit data from 113 cells spanning a range of retinal locations from $\sim 1.5$ to $7 \mathrm{~mm}$ from the foveal center $(\sim 7-$ $40^{\circ}$ retinal eccentricity) using a DoG center-surround receptive field model (Enroth-Cugell et al., 1983) for the F1 and a Gaussian receptive field model for the F2. Examples of F1 and F2 spatial frequency responses and the full-center radii from the fits from 16 cells at a range of retinal eccentricities are illustrated in Figure $6 \mathrm{~A}$. The F1 and F2 components in response to drifting and counterphase-modulated gratings, respectively, are plotted. Examples of central, midperipheral, and far peripheral cells are shown in the vertical columns. The F1 component (filled circles) center size varies with retinal recording location, as would be expected because parasol dendritic tree size increases with increasing retinal eccentricity. In contrast, the much finer center diameters for the F2 component are relatively stable with variation in eccentricity. Data from the model fits for all 113 cells are summarized in Figure $6, B$ and $C$, and a summary of the fit parameters are listed in Table 1. To better compare physiological and anatomical measurements of dendritic field size, we defined "full center" to be equivalent to three times the Gaussian radius (for rationale, see Materials and Methods) (Peichl and Wässle, 1979, 1983; DeVries and Baylor, 1997; Lee, 1999). This gave F1 center diameters with a mean and SD of $177 \pm 69$ $\mu \mathrm{m}$ and range of $52-469 \mu \mathrm{m}$, and for the $\mathrm{F} 2,48 \pm 20 \mu \mathrm{m}$, with a range of $18-125$ $\mu \mathrm{m}(n=113)$. The $\mathrm{F} 1$ range fits nicely with the dendritic field size range of parasol cells (mean $\pm \mathrm{SD}, 209 \pm 70 \mu \mathrm{m}$; range, $31-400 \mu \mathrm{m} ; n=348$ ) over the retinal eccentricities that we recorded (Fig. $6 \mathrm{~B}$, inset). Because the F2 dimensions vary little, the ratio of $\mathrm{F} 1$ to $\mathrm{F} 2$ center diameters ranges from $\sim 1: 1$ to $10: 1$ with the F2 on average being approximately one-fourth the diameter of the F1 center.
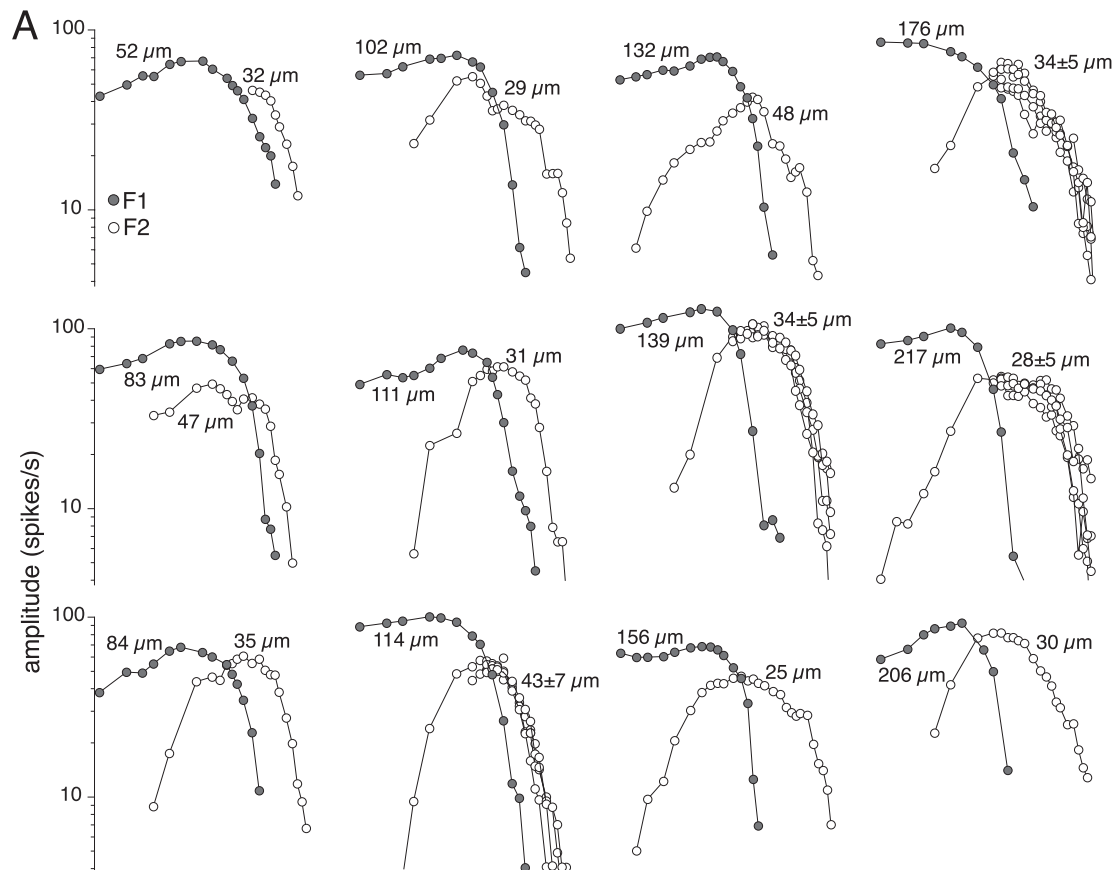

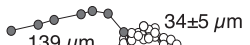
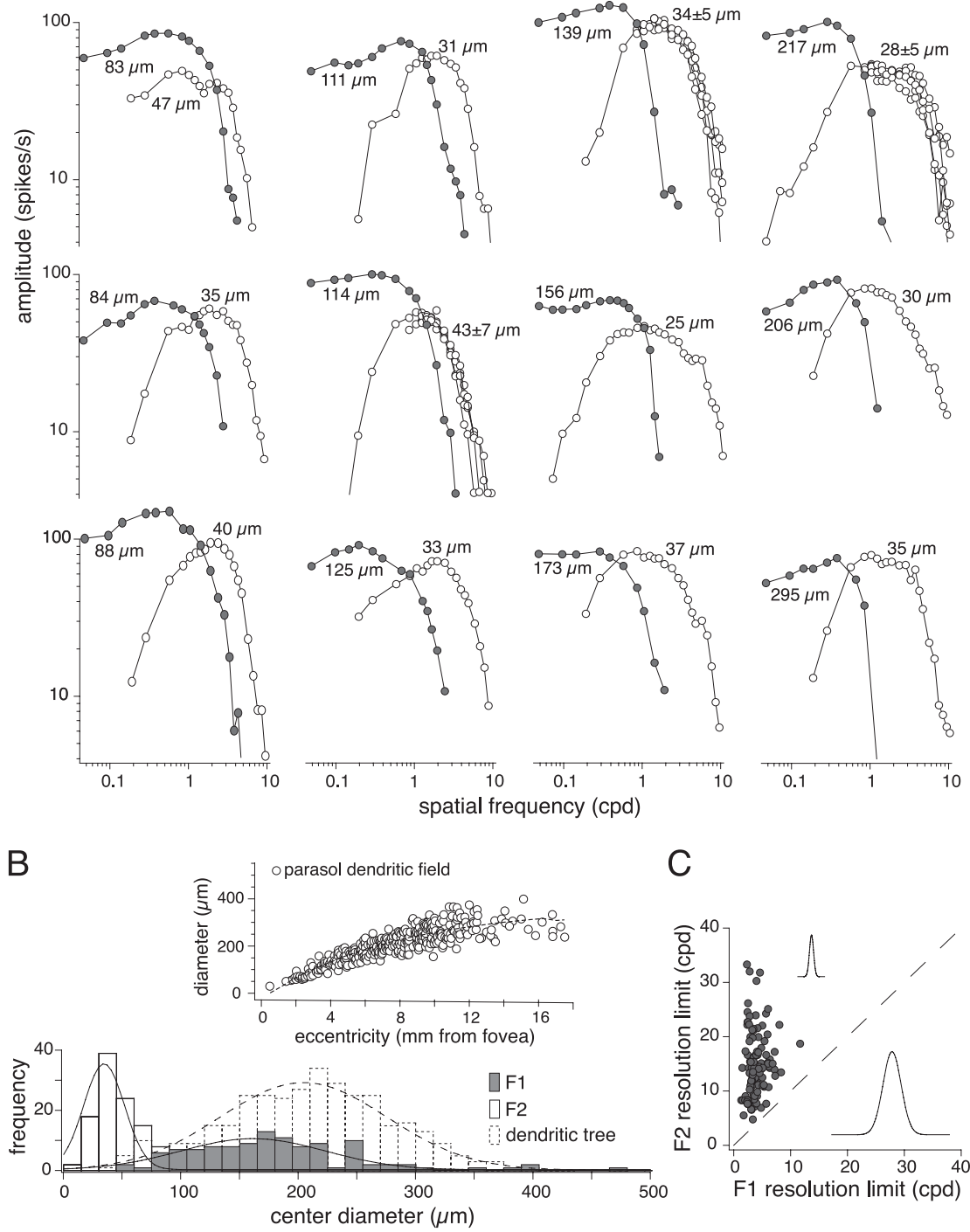

C

Figure 6. Parasol cells of all eccentricities exhibit Y-like second harmonic responses to counterphase gratings. At spatial frequencies beyond which the parasol cell fails to exhibit a response at the stimulus frequency (i.e., the F1), it continues to evoke phase insensitive responses at twice that frequency (i.e., the $\mathrm{F} 2$ ). $\boldsymbol{A}$, Sixteen parasol $\mathrm{Y}$-cell signature examples, taken from a range of eccentricities. Stimulus conditions were the same as those in Figure 5, A and D. B, C, For 113 parasol cells, the F1 curves were fit with a difference of Gaussian center-surround receptive field model and the high-spatial-frequency limb of the F2 curve was fit with a Gaussian model. The Gaussian radii were multiplied by 3 to estimate the center diameter equivalent to that of a dendritic tree and are included in each plot. For the examples with four $\mathrm{F} 2$ spatial frequency tuning curves (each collected at a different spatial phase; $0,45,90$, or $135^{\circ}$ ) the mean center receptive field diameter is included (error bars indicate 1 SD). B. Histograms of center diameter sizes for the $\mathrm{F} 2$ receptive field (open bars), $\mathrm{F} 1$ receptive field (solid gray bars), and parasol dendritic tree (dotted bars). Inset includes parasol dendritic tree diameter as a function of eccentricity $(n=348)$. The median center diameter for the F1 was $173 \mu \mathrm{m}$ (quartile range, 126-212), and for the $\mathrm{F} 2$ was $42 \mu \mathrm{m}$ (quartile range, 35-38). The F1 full-center receptive field diameter was, on average, approximately four times larger than the $F 2$. C, F1 versus $F 2$ spatial resolution limit (cycles per degree). At the cells' spatial frequency resolution limit, three sinusoidal cycles are expected to fit into the full-center receptive field diameter (Crook et al., 1988; Lee, 1999). Insets are two-dimensional profiles of the model fits (F2 above and F1 below).

\section{F1 and F2 share high contrast gain and temporal sensitivity}

It is possible that the rectified $\mathrm{F} 2$ response component reflects a response distortion present at a limited range of higher contrasts and low temporal frequencies. We therefore characterized and 
Table 1. F1 difference of Gaussians and F2 Gaussian fit parameters

\begin{tabular}{|c|c|c|c|c|c|c|}
\hline & Gaussian center ( $\mu \mathrm{m})$ & Gaussian surround ( $\mu \mathrm{m})$ & Center phase (radians) & Surround phase (radians) & $\begin{array}{l}\text { Center surround } \\
\text { weight }\end{array}$ & Center weight \\
\hline F10N & $62.5 \pm 22.7(n=70)$ & $317.8 \pm 131.04(n=69)$ & $0.3 \pm 0.7(n=70)$ & $-2.8 \pm 0.9(n=69)$ & $1.9 \pm 1.1(n=69)$ & \\
\hline F10FF & $52.9 \pm 22.7(n=43)$ & $305.04 \pm 19.7(n=42)$ & $-3.0 \pm 0.7(n=43)$ & $-0.2 \pm 0.8(n=42)$ & $1.8 \pm 0.6(n=42)$ & \\
\hline F2 ON & $15.8 \pm 0.03(n=70)$ & & & & & $40.0 \pm 27.2(n=70)$ \\
\hline F2 OFF & $15.9 \pm 0.03(n=43)$ & & & & & $54.6 \pm 20.8(n=43)$ \\
\hline
\end{tabular}

compared the temporal contrast sensitivities of the F1 and F2 components in the same parasol ganglion cells. Drifting (F1) and contrast-reversing (F2) gratings of optimal spatial frequency were used (Fig. 7). The F2 component like the F1 was clearly present even at $3 \%$ contrast, the lowest contrast used (Fig. $7 A, B$ ). Data plotted for several cells at $50 \%$ contrast as a function of temporal frequency (Fig. 7 C) shows that the F2 consistently rolls off at slightly lower temporal frequencies than the F1 response. Average F1 and F2 $10.5 \mathrm{~Hz}$ response versus contrast functions were fit well with a Naka-Rushton function (see Materials and Methods) yielding high contrast sensitivity (Fig. 7D). Such curves are characterized by the initial slope (contrast gain, $a / b$ ). The F1 response had higher contrast gain values than the $\mathrm{F} 2(\mathrm{~F} 1$, mean \pm $\mathrm{SD}, 4.5 \pm 2.2 ; n=12 ; \mathrm{F} 2$, mean $\pm \mathrm{SD}, 2.1 \pm 1.0 ; n=12)$. Figure $7 E$ summarizes the above data by plotting contrast gain as a function of temporal frequency ( $x$-axis vs $y$-axis). The $z$-axis denotes the average F1 and F2 spatial frequencies used to gather the data. This plot illustrates the basic shift in spatial frequency tuning for the F1 and F2 components, but with a similar profile for contrast gain as a function of temporal frequency.

\section{F2 component is spatially restricted to the excitatory center}

In a previous study of guinea pig alpha-Y cells (Demb et al., 2001), blockade of inner retinal inhibitory pathways with TTX or antagonists of GABAergic, glycinergic, or cholinergic transmission did not reduce the F2 spatial component. This study also showed that the excitatory F2 component was precisely coextensive with the linear receptive field center. These and other results led to the conclusion that the F2 component was driven by glutamatergic input to the $\mathrm{Y}$ cell from transient, partially rectifying cone bipolar cells. Here, we show results for the macaque parasol-Y cell consistent with this general hypothesis. We found that when the linear receptive field structure was measured with sinusoidally modulated spots of increasing diameter or annuli of increasing inner diameter, the basic center and surround components of the receptive field could be isolated (Fig. $8 \mathrm{~A}$ ). However, in the same cell, when the same stimuli were used containing counterphase-modulated grating stimuli at the optimal spatial frequency for the F2 component, frequency doubling was restricted to the approximate diameter of the F1 receptive field center (Fig. $8 \mathrm{~B}$ ). The spatial restriction of the F2 component to the receptive field center was also evident if the $\mathrm{F} 2$ response was measured as a function of spatial frequency using grating stimuli restricted to the center versus the surround of the receptive field (Fig. $8 C, D$ ). In this situation, peak spike rates for the F2 response at optimal spatial frequencies were similar whether gratings were full field (Fig. $8 C$ ) or restricted to the receptive field center in a small spot (Fig. $8 D$ ). In contrast, annular stimuli containing gratings did not give rise to a comparable $\mathrm{F} 2$ response at any spatial frequency tested. The area threshold plots for spot and annuli stimuli shown in Figure $8 \mathrm{~A}$ were fit with the difference of Gaussians receptive field model. The area threshold plots for spot and annuli containing contrast-reversing gratings (Fig. $8 \mathrm{~B}$ ) were fit with the single Gaussian model. The Gaussian center radius determined for a spot was $69 \pm 28 \mu \mathrm{m}(n=7)$ and for a contrast-reversing grating in a spot was $81 \pm 36 \mu \mathrm{m}(n=7)$, demonstrating that the field of subunits responsible for the F2 component of response and the receptive field center measured for the F1 component of response are comparable in diameter.

\section{Inhibitory blockade can elevate the $\mathrm{F} 2$ component}

Also consistent with previous results for guinea pig alpha-Y cells, we found that block of inhibitory pathways with bath application of picrotoxin and strychnine did not attenuate or reduce the F2 component. Instead, the F2 and F1 full-center receptive field diameters and peak spike rates increased somewhat (Figs. $8 \mathrm{E}-\mathrm{H}$, $9 B, C)$. The average percentage increases calculated from a cellby-cell comparison for the F1 center size and peak response were $14 \pm 21 \%$ and $12 \pm 65 \%$ (mean $\pm \mathrm{SD} ; n=18)$, respectively, and for the $\mathrm{F} 2$ center size and peak response, $47 \pm 64 \%$ and $57 \pm 41 \%$ (mean $\pm \mathrm{SD} ; n=18$ ), respectively. We did not systematically study potential ON- versus OFF-cell differences here, but we noted a particularly clear effect in ON-center cells (compare Figs. $8 E, F, 9 B, C)$. For all $\mathrm{ON}$ cells in the presence of picrotoxin and strychnine, the normally transient $\mathrm{ON}$ response to a light increment became ON-OFF, even at response threshold (Fig. 9A) $(n=11)$, as well as ON-OFF to low-spatial-frequency drifting gratings and contrast-reversing gratings (Fig. 9C). In Figure 9, $B$ and $C$, we plot the Y-cell signature, as in previous figures, for control and inhibitory block; alongside each plot spike, histograms from responses to the contrast-reversing gratings are illustrated at $0.047-1.034 \mathrm{cpd}$ for spatial phases $0,45,90$, and $135^{\circ}$. The dominant F1 component at low spatial frequencies, which is prominent when the spatial phase is set to 0,45 , or $135^{\circ}$, is replaced after an inhibitory block with a frequency-doubled response at all spatial phases. Unlike the frequency doubling at high spatial frequencies, the response amplitude is phase sensitive (see $90^{\circ}$ phase). Thus, under normal conditions at low spatial frequencies, the F1 dominated $67 \pm 0.07 \%$ (mean $\pm \mathrm{SD}$ ) of the parasol cell response $[\mathrm{F} 1 /(\mathrm{F} 1+\mathrm{F} 2) ; n=9]$. In the presence of the inhibitory blockers, the F2 component dominated $62 \pm 0.19 \%$ $($ mean $\pm \mathrm{SD})$ of the response $[\mathrm{F} 2 /(\mathrm{F} 2+\mathrm{F} 1) ; n=9]$.

\section{Discussion}

\section{Parasol cells project to the superior colliculus}

Despite the assertion that macaque parasol cells, like the beta-X cells of the cat, project exclusively to the LGN (Shapley and Perry, 1986), evidence for a collicular projection can be found in the first anatomical experiments to address the question (Bunt et al., 1975; Leventhal et al., 1981). At approximately the same time, the fastest conducting Y-like ganglion cells that projected to the magnocellular LGN were also antidromically activated from the superior colliculus (Schiller and Malpeli, 1977; DeMonasterio, 1978). This anatomical and physiological data appeared to show conclusively that the ganglion cells with the largest cell bodies and 
thickest axons, referred to currently as parasol cells, projected to the superior colliculus. However, two more recent retrograde tracing studies (Perry and Cowey, 1984; Rodieck and Watanabe, 1993) suggested the absence of a parasol-collicular projection. These negative results may reflect the degree to which parasol cells could be identified with the methods used. In one study (Rodieck and Watanabe, 1993), the emphasis was on identifying novel ganglion cell types by targeting a relatively small number of cells for intracellular staining. In the present study, after collicular injections, parasol cells were clearly evident among diverse ganglion cell types (Fig. 2), when hundreds of retrogradely labeled cells were photostained. This technique revealed their fine dendritic morphology and their characteristic pattern of retinal tiling (Fig. 3), suggesting strongly that as a population this cell class projects to the colliculus.

A collicular projection strengthens the hypothesis that macaque parasol cells are the correlate of the generic mammalian alpha cell; indeed, there seems little anatomical data to argue against this conclusion (Peichl et al., 1987; Peichl, 1991). The only morphological property that does not match with the alpha cell pattern is that macaque parasol cells are present at a higher spatial density than alpha cells in other mammals (Silveira and Perry, 1991). Given the very high cone and ganglion cell densities of the primate, it is necessary to compare parasol cells with other mammalian alpha cells at comparable densities; when this is done, alpha and parasol cells fall into close alignment (Rodieck et al., 1993).

\section{The parasol Y-cell signature}

The earliest physiological characterization of presumed parasol cells and their magnocellular counterparts also suggested a correspondence to the cat's alpha-Y cell (Dreher et al., 1976; Sherman et al., 1976; DeMonasterio, 1978; Schiller and Malpeli, 1978; Marrocco et al., 1982). These previous studies failed to demonstrate a clear Y-cell receptive field signature for magnocellular pathway neurons, but the means of classifying Y-cells (Hochstein and Shapley, 1976a,b) were not yet well established. Subsequent studies at the LGN level addressed this question; all concluded that Y-cells were present, but that the majority of magnocellular relay cells showed linear spatial summation (Kaplan and Shapley, 1982; Derrington and Lennie, 1984; Blakemore and Vital-Durand, 1986; Spear et al., 1994; Levitt et al., 2001; White et al., 2001),
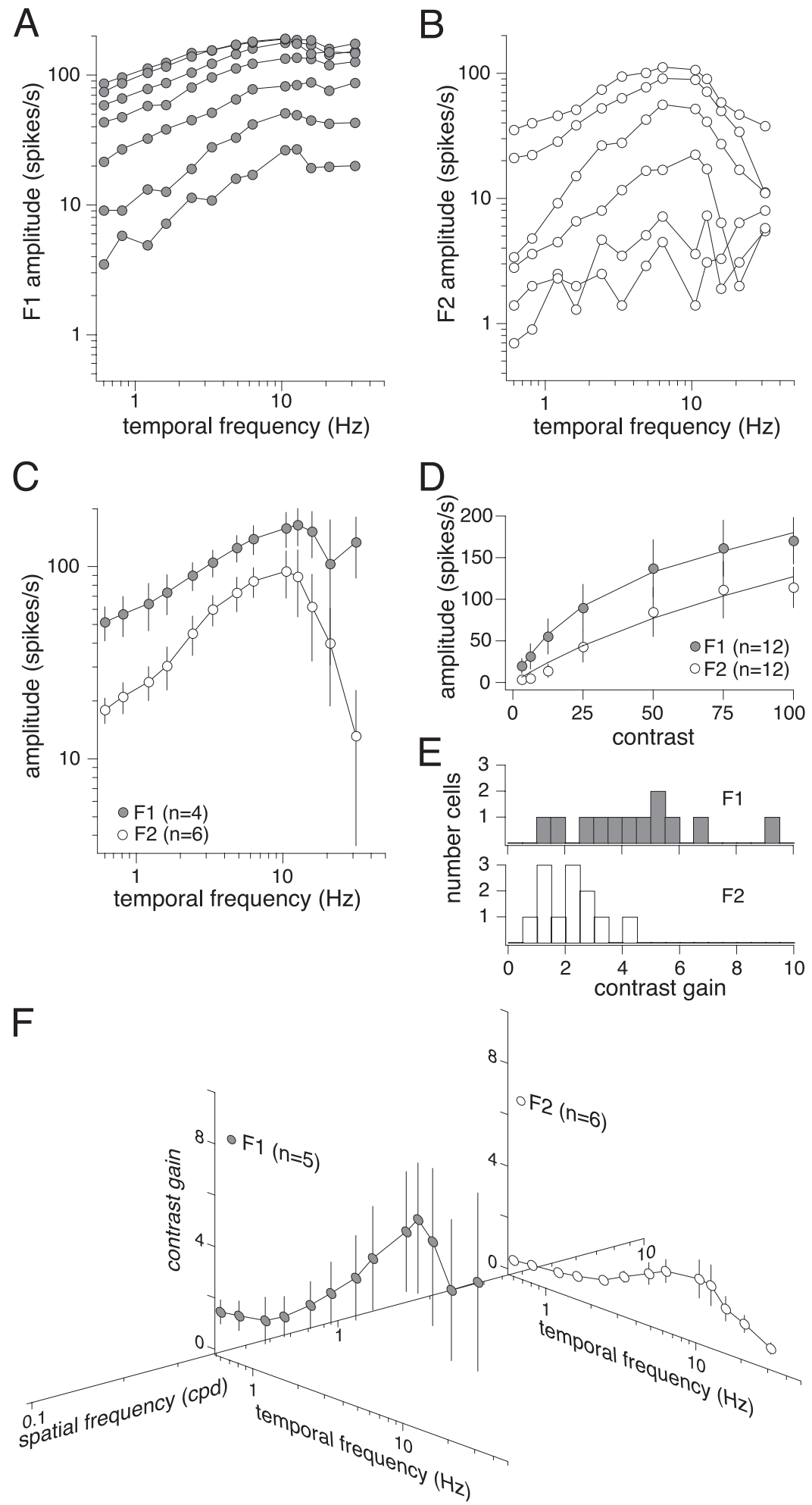

Figure 7. The $\mathrm{F} 2$ component of parasol cells, like the $\mathrm{F} 1$, is sensitive to a range of contrasts and temporal frequencies. $A, B, F 1$ and $F 2$ responses from the same cell measured with drifting and contrast-reversing gratings of optimal spatial frequency, respectively, as a function of temporal frequency ranging from 0.61 to $31.51 \mathrm{~Hz}$ at $3.125,6.25,12.5,25,50,75$, and $100 \%$ contrast. C, Mean F1 (gray solid circles, $n=5$ ) and F2 (open circles, $n=6$ ) temporal modulation transfer functions at $50 \%$ contrast for optimal spatial frequency (error bars indicate 1SD). The average peak response was $13 \mathrm{~Hz}(n=5)$ for the $\mathrm{F1}$, and $11 \mathrm{~Hz}(n=6)$ for the F2. $\boldsymbol{D}$, Mean F1 (gray solid circles) and F2 (open circles) contrast-response functions with Naka-Rushton fits (as described in $\boldsymbol{A}$ with data collected at $10.5 \mathrm{~Hz}$; error bars indicate 1 SD). Curves are characterized by their contrast gain defined as the maximal response in impulses per second divided by the semisaturation constant $(a / b)$. $\boldsymbol{E}$, Histogram of individual contrast gain values for responses in $\boldsymbol{D}$ (F1, gray bars, $n=12 ; \mathrm{F2}$, open bars, $n=12$ ). $\boldsymbol{F}$, Average F1 (solid circles, $n=5$ ) and F2 (open circles, $n=6$ ) contrast gain values as a function of temporal frequency (error bars indicate 1SD). The $z$-axis is spatial frequency, denoting the average optimal spatial frequency used to collect the F1 and F2 contrast gain values. The average optimal F2 spatial frequency is $\sim 10$ times that of the average optimal $\mathrm{F} 1$ spatial frequency and well beyond its spatial frequency resolution. 
A
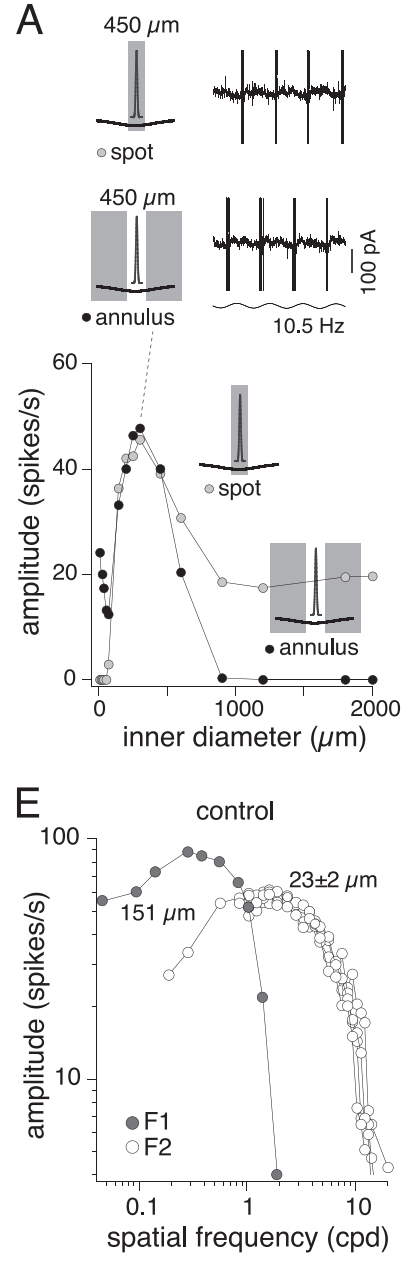

B
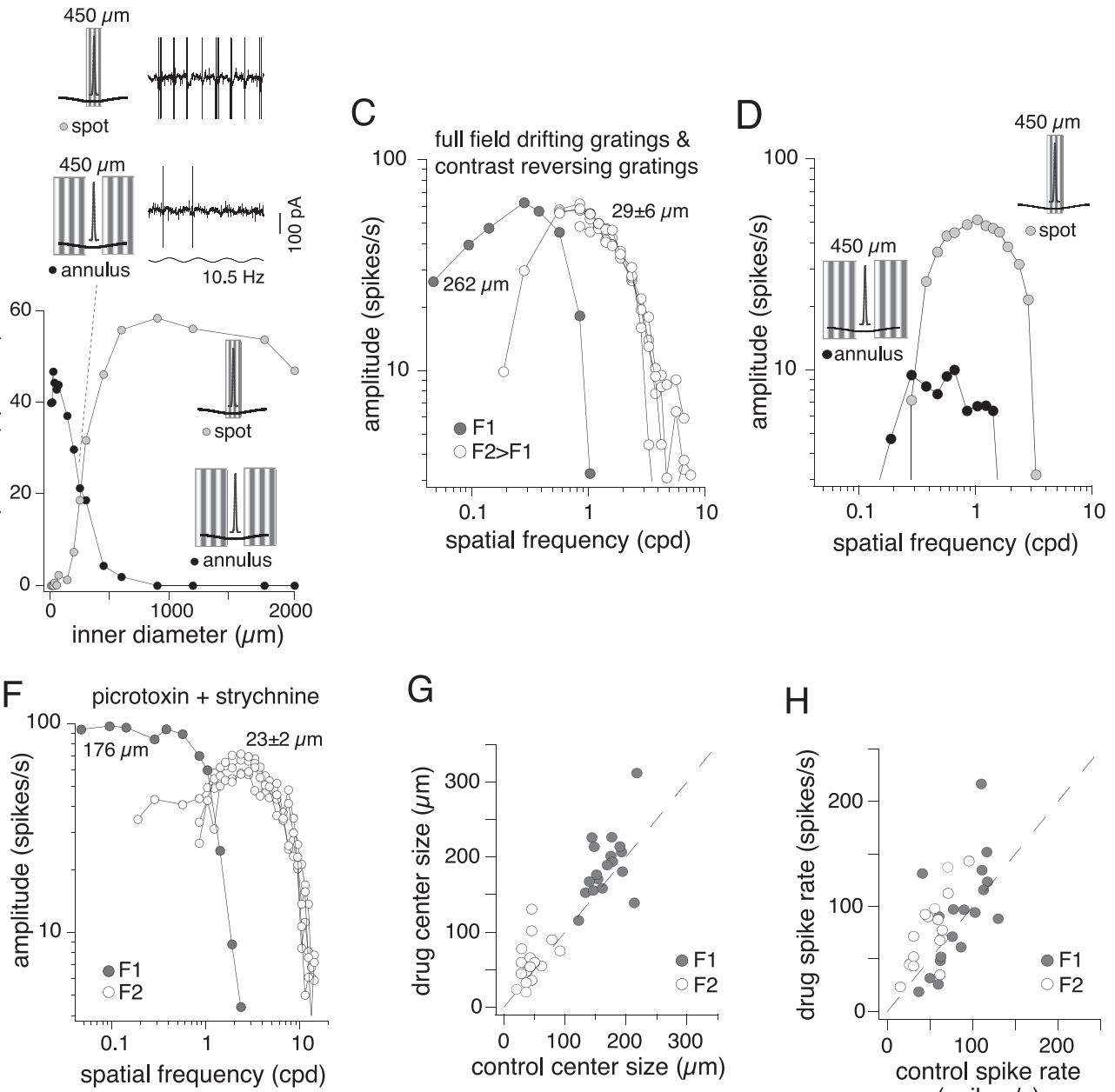

G

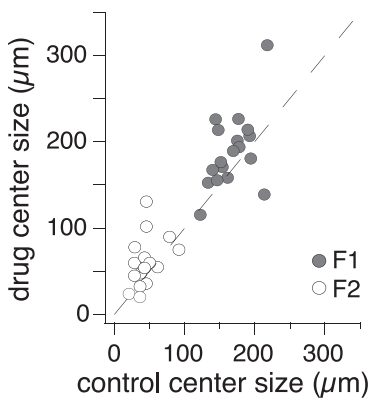

$\mathrm{H}$

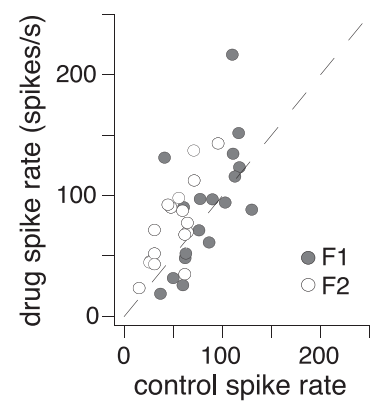

(spikes/s)

Figure 8. Parasol cells $F 2$ response is excitatory and localized predominantly to the center component of the receptive field. $A, F 1$ area summation curves for spot (gray circles) and annulus (black circles) stimuli sinusoidally modulated at $10.5 \mathrm{~Hz}$ and $50 \%$ contrast. The outer annulus diameter was always $2 \mathrm{~mm}$. Insets, Four cycles of traces to a 450- $\mu \mathrm{m}$-diameter spot (top) and $450-\mu \mathrm{m}$ inner-diameter annulus (bottom) with stimulus trace below. B, F2 area summation curves for spot (gray circles) and annuli (black circles) containing contrast-reversing gratings of optimal spatial frequency sinusoidally modulated at $10.5 \mathrm{~Hz}$ and $50 \%$ contrast. Insets, Four cycles of responses to a $450 \mu \mathrm{m}$ diameter spot (top) and a 450 - $\mu \mathrm{m}$-inner-diameter annulus (bottom) with stimulus trace below. The parasol cell frequency doubled to the spot but not to the annulus stimulus. $C$, Parasol Y-cell signature as described in Figure 5D. D, F2 responses, from the same cell in $\boldsymbol{C}$, to contrast-reversing gratings in a 450- $\mu \mathrm{m}$-diameter spot (gray circles) and 450- $\mu \mathrm{m}$-inner-diameter annulus (black circles) as a function of the spatial frequency. Data in $A-D$ are from the same cell. $E, F, 0$ FF parasol cell $Y$-cell signatures (as for Fig. 5D) before and after the addition of GABA and glycine antagonists picrotoxin and strychnine. Insets include F1 and F2 (mean \pm SD) full-center receptive field diameter measurements as described in Figure 6 A. $\mathbf{G}, \boldsymbol{H}$, The addition of inhibitory drugs had little effect on the cells spatial tuning and response strength. $\mathbf{G}, \mathrm{F} 1$ (gray circles) and F2 (open circles) full-center receptive field diameters before and after the application of picrotoxin and strychnine ( $n=18$ ). $\boldsymbol{H}, \mathrm{F} 1$ (gray circles) and F2 (open circles) peak responses (spikes per second) before and after the application of picrotoxin and strychnine $(n=18)$.

as have recent experiments recording from parasol ganglion cells (White et al., 2002; Petrusca et al., 2007).

How can our demonstration of a reliable Y-cell signature in macaque parasol cells be reconciled with this previous work? Surprisingly, most of these studies did not systematically measure spatial frequency responses of the F2 component, but relied on a shortcut in which the ratio of F2 to F1 amplitude is used as an "index" of nonlinearity. As originally applied (Hochstein and Shapley, 1976b), the nonlinearity index would identify the largest F2-F1 ratio across the full spatial frequency range. Cat $\mathrm{X}$-cells showed a maximum $\mathrm{F} 2-\mathrm{F} 1$ ratio $<1$, and $\mathrm{Y}$-cells always showed a ratio $>1$, indicative of the higher spatial frequency resolution of the F2 component (Fig. 5). Indeed, for cells with a clear Y-cell signature, the F2 component extends three to five times beyond the spatial frequency response of the F1 component, and F2-F1 ratio thus approaches infinity. In some of the previous studies, this nonlinearity index was measured at a fixed spatial frequency, at or just beyond the F1 response peak, a location that would in fact make it difficult to observe separation of the spatial frequency resolution of F1 and F2 components and greatly underestimate any spatial nonlinearity present (Derrington and Lennie, 1984; Blakemore and Vital-Durand, 1986; White et al., 2001, 2002). In other experiments, high spatial frequencies, $\sim 10 \mathrm{cpd}$ and above, were not explored (Levitt et al., 2001; Petrusca et al., 2007), again leading to a potential underestimate of the resolution of the F2 component. In addition, a potentially critical technical limitation shared by all of the previous studies working with the acutely anesthetized intact animal is the natural blurring of the extrafoveal retinal image, where most recordings are made (Williams et al., 1996), compounded by the recognized difficulty of optimizing and maintaining image quality. In many of these experiments, contrast at spatial frequencies of $10 \mathrm{cpd}$ and above may be greatly attenuated in the optical image cast on the retina. Working with the retina in vitro, we were able to directly focus our stimulus on the retina 

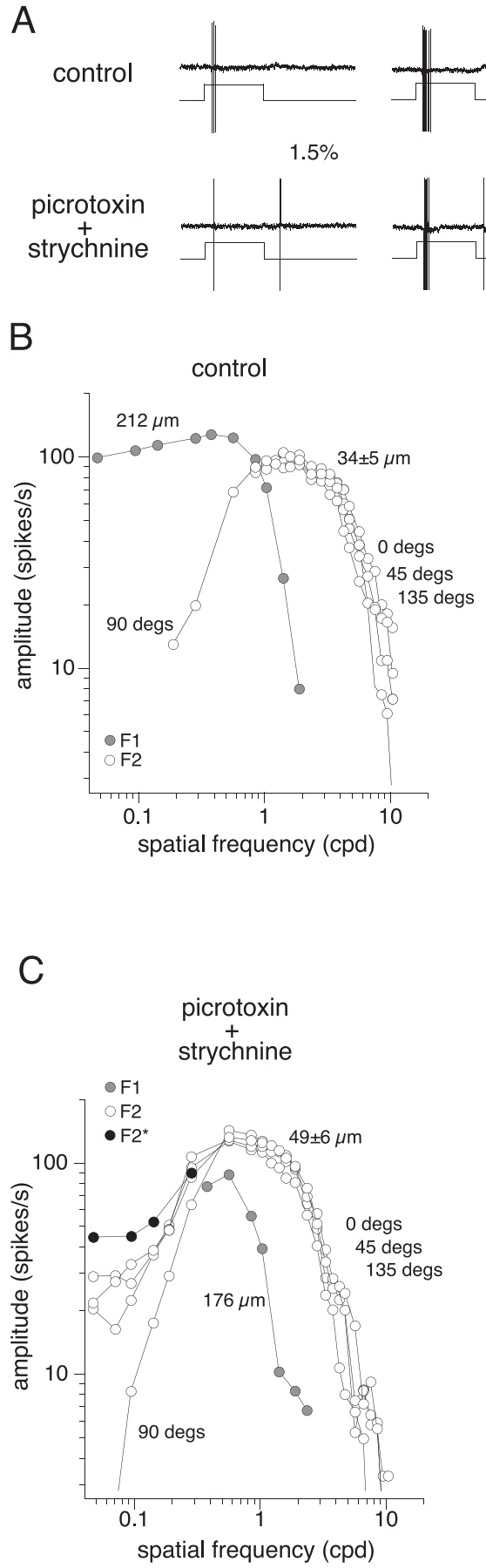
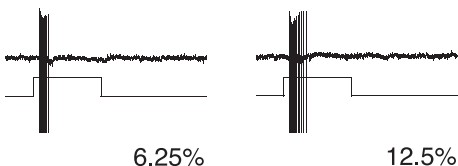

$3.125 \%$
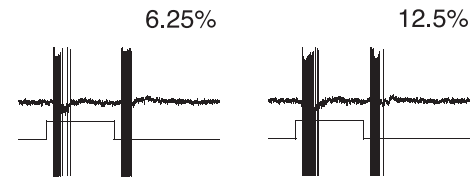

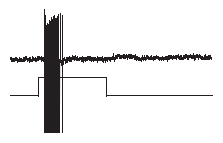

$25 \%$
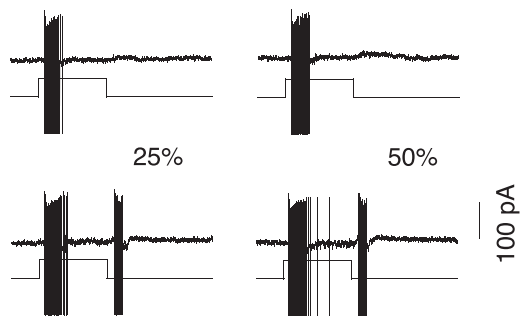
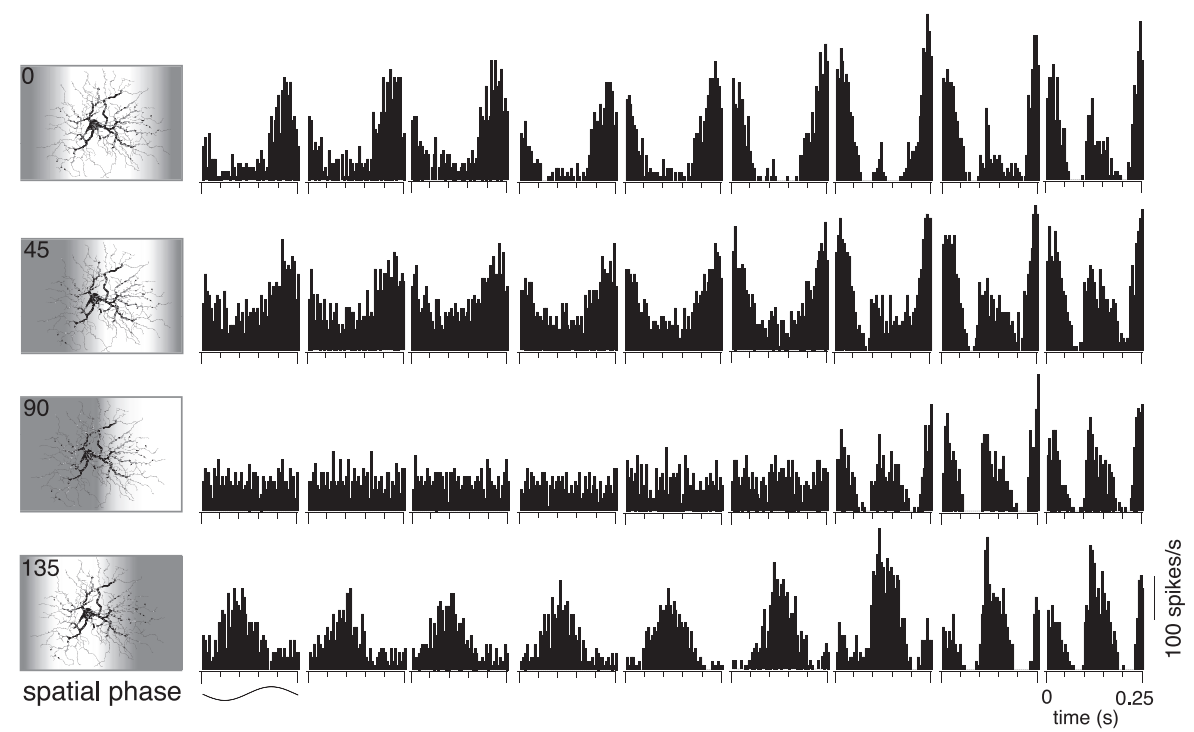

spatial phase

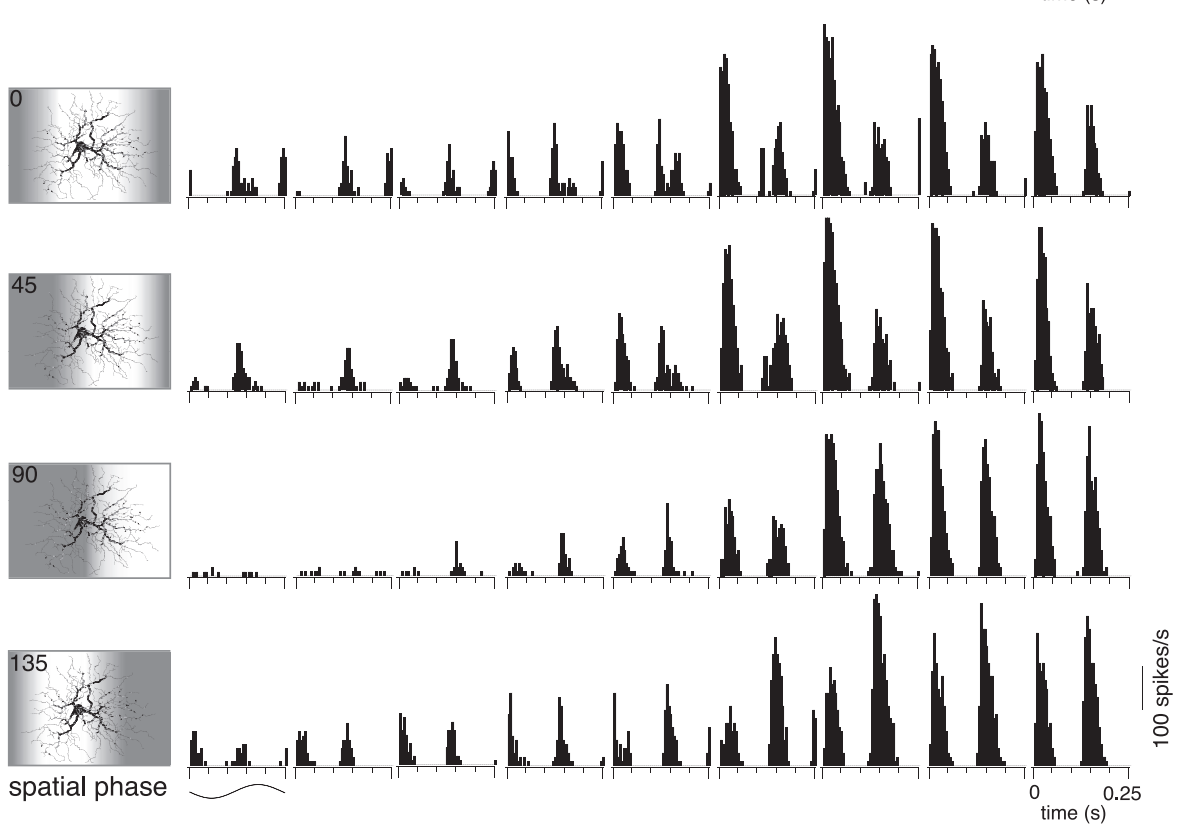

Figure 9. Inhibitory circuits contribute to linear spatial summation at low spatial frequencies. $\boldsymbol{A}$, Responses to a $500 \mathrm{~ms}$ pulse of a $200-\mu \mathrm{m}$-diameter centered spot presented at a range of contrasts on a black background before (above) and after application of picrotoxin and strychnine (stimulus trace below). B, C, Parasol Y-cell signatures, as for Figure 5D, and corresponding average peristimulus time histograms to one cycle of the contrast-reversing grating (stimulus trace below) for spatial frequencies between 0.047 and $1.034 \mathrm{cpd}$, increasing from left to right before ( $\boldsymbol{B}$ ) and after $(\boldsymbol{C})$ treatment with picrotoxin and strychnine. In the presence of the inhibitory antagonists, the parasol cells $\mathrm{F} 2$ dominates at all spatial frequencies to the contrast-reversing grating. $\mathrm{F2}$ responses also dominate to drifting gratings of low spatial frequency $\left(\mathrm{F} 2^{*}\right)$.

under microscopic control and to evaluate the contrast achieved at high spatial frequencies by direct measurement made in the plane of the retina (Packer et al., 2001). Our methods are thus more comparable to another recent study, also recording from the macaque retina in vitro and measuring spatial nonlinearities in ganglion cells (Petrusca et al., 2007).
In this study, parasol cells from the far retinal periphery displayed clear spatial nonlinearity, although Petrusca et al. (2007) did not explore spatial frequencies greater than $\sim 5 \mathrm{cpd}$ nor the temporal or contrast sensitivity measurements that might have permitted a more complete spatial delineation of the parasol F2 component. They also reached the conclusion 


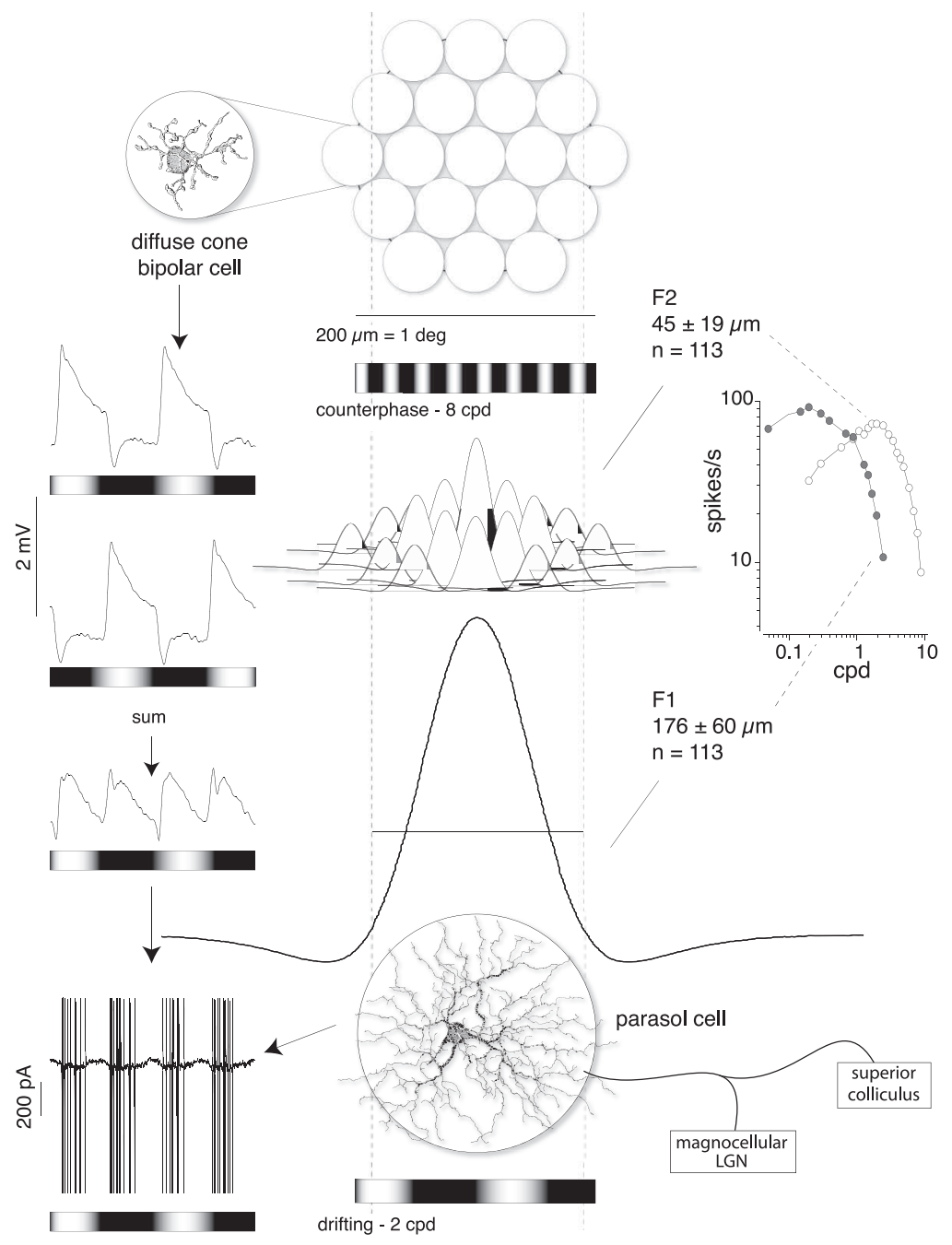

Figure 10. Summary of the major results of this study and hypothesis for the origin of the $F 2$ receptive field component in parasol cells. At top a spatial array of circular receptive fields of diffuse bipolar cells that provide excitatory input to the dendritic tree of the parasol ganglion cell. We hypothesize, following the work of Demb et al. (2001), that the F2 component derives from the combined outputs of these bipolar cells in response to counterphase-modulated gratings at high spatial frequencies. The small diameters (Fig. 6), temporal and contrast sensitivity (Fig. 7), resistance to inhibitory block (Figs. 8, 9), and spatial restriction to the receptive field center (Fig. 9) all support this hypothesis. On the left side of the figure, intracellular recordings from a diffuse bipolar cell (Dacey et al., 2000) indicate the transient, partially rectified responses of these cells, and how the synaptic potentials in response to the light and dark phases of the counterphase modulation could sum at the ganglion cell to give rise to a frequencydoubled input and resultant spike discharge in the parasol ganglion cell. Fits to the F1 and F2 spatial frequency data (illustrated in the plot on the right) with a difference-of-Gaussians and Gaussian summation model, respectively, are shown in the center. For comparison, the mean $\mathrm{F} 1$ response diameter (given as 3 times the Gaussian radius) measured with drifting gratings is shown in relation to a parasol dendritic tree (center, bottom). The $\mathrm{F} 1$ diameter matches that of a midperipheral ganglion cell where the majority of cells were recorded; however, F1 diameters vary systematically with retinal eccentricity as expected (Fig. 6B). F2 diameters are relatively constant across the retina presumably reflecting the relative constancy of bipolar cell field diameters as a function of eccentricity.

that parasol cells were not a viable candidate for a primate alpha-Y cell, adhering to the prevailing view.

\section{Cone bipolar origin of the F2 component}

The F2 high temporal and contrast sensitivity, small-diameter receptive field (Figs. 6,7), spatial restriction to the linear receptive field center (Fig. 8), and resistance to inhibitory block (Figs. 8, 9) all support the hypothesis that transient cone bipolar cells are the source of the rectifying nonlinearity that generates the Y-cell signature. This hypothesis follows closely the conclusion from a previous study of the alpha-Y cell type of the guinea pig retina (Demb et al., 2001), and further rein- forces the conclusion that parasol cells are the primate alpha-Y cell. The essence of the bipolar cell hypothesis was captured previously in the pooled subunit model for the cat alpha-Y cell receptive field (Cleland, 1983; Enroth-Cugell and Freeman, 1987) in which the same excitatory subunits give rise to both the linear receptive field component and the F2 component. The results of Demb et al. (2001) added evidence that the major nonlinear mechanism is not dependent on inhibition interposed between the bipolar cells and the ganglion cell, but that the cone bipolar cells are likely to be inherently transient and partially rectifying. It is worth emphasizing that this implies that the nonlinearity responsible for the Y-cell signature is localized to the receptive field center alone. Our results support this picture. We summarize the case for parasol cells in Figure 10 by illustrating how the transient, partially rectified responses of a macaque diffuse cone bipolar cell type (Dacey et al., 2000) could, in response to counterphasemodulated gratings, sum at the ganglion cell to give rise to the F2 component in the ganglion cell spike discharge.

Our results, and the comparable results for guinea pig Y-cells (Demb et al., 2001), differ from the classic model developed for cat-Y cells (Hochstein and Shapley, 1976b; Victor and Shapley, 1979), in which the linear subunits are pooled by input to a presumptive amacrine cell and it is the inhibitory amacrine that is the site of the rectifying nonlinearity. This model may serve the case of nonlinear response suppression to high-spatial-frequency stimulation from beyond the classical Y-cell receptive field (Enroth-Cugell and Jakiela, 1980; Krüger, 1980; Passaglia et al., 2001), recently shown for both parasol and guinea pig Y-cells (Solomon et al., 2006; Zaghloul et al., 2007). It is thus important to note that all of our stimuli were restricted mostly to the classical center-surround receptive field, and we have not explored potential long-range inhibitory effects on the F2 component described here.

The origin of the F2 component from spatial summation of cone bipolar cells with transient, partially rectified responses is consistent with the early origin of such temporal filtering at the photoreceptor-bipolar synapse (Awatramani and Slaughter, 2000; DeVries, 2000; Euler and Masland, 2000; Roska et al., 2000; DeVries et al., 2006) and the evidence that the great majority of ganglion cell types show nonlinear spatial summation (Amthor et al., 1989; Troy et al., 1989, 1995; Rowe and Cox, 1993; Pu et al., 1994; Demb et al., 1999). One of these other Y-cell types in the primate, with a distinctive relationship to the parasol pathway, is the subject of a companion study (Crook et al., 2008). 


\section{References}

Amthor FR, Takahashi ES, Oyster CW (1989) Morphologies of rabbit retinal ganglion cells with concentric receptive fields. J Comp Neurol 280:72-96.

Awatramani GB, Slaughter MM (2000) Origin of transient and sustained responses in ganglion cells of the retina. J Neurosci 20:7087-7095.

Baylor DA, Nunn BJ, Schnapf JL (1987) Spectral sensitivity of cones of the monkey Macaca fascicularis. J Physiol 390:145-160.

Benardete EA, Kaplan E (1999) The dynamics of primate M retinal ganglion cells. Vis Neurosci 16:355-368.

Benardete EA, Kaplan E, Knight BW (1992) Contrast gain control in the primate retina: $\mathrm{P}$ cells are not $\mathrm{X}$-like, some $\mathrm{M}$ cells are. Vis Neurosci 8:483-486.

Blakemore C, Vital-Durand F (1986) Organization and post-natal development of the monkey's lateral geniculate nucleus. J Physiol 380:453-491.

Bunt AH, Hendrickson AE, Lund JS, Lund RD, Fuchs AF (1975) Monkey retinal ganglion cells: morphometric analysis and tracing of axonal projections with a consideration of the peroxidase technique. J Comp Neurol 164:265-285.

Cleland BG (1983) Centre and surround properties of the receptive fields of $\mathrm{X}$ and $\mathrm{Y}$ ganglion cells in the cat retina. Proc Aust Physiol Pharmacol Soc 14:192-201.

Cleland BG, Levick WR (1974) Properties of rarely encountered types of ganglion cells in the cat's retina and an overall classification. J Physiol 240:457-492.

Cleland BG, Levick WR, Wässle H (1975) Physiological identification of a morphological class of cat retinal ganglion cells. J Physiol 248:151-171.

Croner LJ, Kaplan E (1995) Receptive fields of P and M ganglion cells across the primate retina. Vision Res 35:7-24.

Crook JM, Lange-Malecki B, Lee BB, Valberg A (1988) Visual resolution of macaque retinal ganglion cells. J Physiol 396:206-224.

Crook J, Peterson B, Packer O, Robinson F, Gamlin P, Troy J, Dacey DM (2008) The smooth monostratified ganglion cell: evidence for spatial diversity of the Y-cell pathway to the LGN and superior colliculus in the macaque monkey. J Neurosci, in press.

Dacey D, Packer OS, Diller L, Brainard D, Peterson B, Lee B (2000) Center surround receptive field structure of cone bipolar cells in primate retina. Vis Res 40:1801-1811.

Dacey DM (2004) Origins of perception: retinal ganglion cell diversity and the creation of parallel visual pathways. In: The cognitive neurosciences, Ed 3 (Gazzaniga MS, ed), pp 281-301. Cambridge: MIT.

Dacey DM, Brace S (1992) A coupled network for parasol but not midget ganglion cells in the primate retina. Vis Neurosci 9:279-290.

Dacey DM, Lee BB (1994) The blue-ON opponent pathway in primate retina originates from a distinct bistratified ganglion cell type. Nature 367:731-735.

Dacey DM, Petersen MR (1992) Dendritic field size and morphology of midget and parasol ganglion cells of the human retina. Proc Natl Acad Sci U S A 89:9666-9670.

Dacey DM, Lee BB, Stafford DK, Pokorny J, Smith VC (1996) Horizontal cells of the primate retina: cone specificity without spectral opponency. Science 271:656-659.

Dacey DM, Peterson BB, Robinson FR, Gamlin PD (2003) Fireworks in the primate retina: in vitro photodynamics reveals diverse LGN-projecting ganglion cell types. Neuron 37:15-27.

Dacy DM, Liao HW, Peterson BB, Robinson FR, Smith VC, Pokorny J (2005) Melanopsin-expressing ganglion cells in primate retina signal colour and irradiance and project to the LGN. Nature 433: 749-754.

Demb JB, Haarsma L, Freed MA, Sterling P (1999) Functional circuitry of the retinal ganglion cell's nonlinear receptive field. J Neurosci 19:9756-9767.

Demb JB, Zaghloul K, Haarsma L, Sterling P (2001) Bipolar cells contribute to nonlinear spatial summation in the brisk-transient $(\mathrm{Y})$ ganglion cell in mammalian retina. J Neurosci 21:7447-7454.

DeMonasterio FM (1978) Properties of concentrically organized X and Y ganglion cells of macaque retina. J Neurophysiol 41:1394-1417.

Derrington AM, Lennie P (1984) Spatial and temporal contrast sensitivities of neurons in lateral geniculate nucleus of macaque. J Physiol 357:219-240.

DeVries SH (2000) Bipolar cells use kainate and AMPA receptors to filter visual information into separate channels. Neuron 28:847-856.
DeVries SH, Baylor DA (1997) Mosaic arrangement of ganglion cell receptive fields in rabbit retina. J Neurophysiol 78:2048-2060.

DeVries SH, Li W, Saszik S (2006) Parallel processing in two transmitter microenvironments at the cone photoreceptor synapse. Neuron 50:735-748.

Diller L, Packer OS, Verweij J, McMahon MJ, Williams DR, Dacey DM (2004) L and M cone contributions to the midget and parasol ganglion cell receptive fields of macaque monkey retina. J Neurosci 24:1079-1088.

Dreher B, Fukada Y, Rodieck RW (1976) Identification, classification and anatomical segregation of cells with X-like and Y-like properties in the lateral geniculate nucleus of old-world primates. J Physiol 258:433-452.

Enroth-Cugell C, Freeman AW (1987) The receptive-field spatial structure of cat retinal Y cells. J Physiol 384:49-79.

Enroth-Cugell C, Jakiela HG (1980) Suppression of cat retinal ganglion cell responses by moving patterns. J Physiol 302:49-72.

Enroth-Cugell C, Robson JG (1966) The contrast sensitivity of retinal ganglion cells of the cat. J Physiol 187:517-552.

Enroth-Cugell C, Robson JG, Schweitzer-Tong DE, Watson AB (1983) Spatio-temporal interactions in cat retinal ganglion cells showing linear spatial summation. J Physiol 341:279-307.

Euler T, Masland RH (2000) Light-evoked responses of bipolar cells in a mammalian retina. J Neurophysiol 83:1817-1829.

Hochstein S, Shapley RM (1976a) Linear and nonlinear spatial subunits in Y cat retinal ganglion cells. J Physiol 262:265-284.

Hochstein S, Shapley RM (1976b) Quantitative analysis of retinal ganglion cell classifications. J Physiol 262:237-264.

Hu EH, Bloomfield SA (2003) Gap junctional coupling underlies the shortlatency spoke synchrony of retinal alpha ganglion cells. J Neurosci 23: $6768-6777$.

Isayama T, Berson DM, Pu M (2000) Theta ganglion cell type of cat retina. J Comp Neurol 417:32-48.

Kaplan E, Shapley RM (1982) X and Y cells in the lateral geniculate nucleus of macaque monkeys. J Physiol 330:125-143.

Kaplan E, Shapley RM (1986) The primate retina contains two types of ganglion cells, with high and low contrast sensitivity. Proc Natl Acad Sci U S A 83:2755-2757.

Krüger J (1980) The shift-effect enhances X- and suppresses Y-type response characteristics of cat retinal ganglion cells. Brain Res 201:71-84.

Lee BB (1999) Receptor inputs to primate ganglion cells. In: Color vision: from genes to perception (Gegenfurtner KR, Sharpe LT, eds), pp 203-218. New York: Cambridge UP.

Leventhal AG, Rodieck RW, Dreher B (1981) Retinal ganglion cell classes in the old world monkey: Morphology and central projections. Science 213:1139-1142.

Levitt JB, Schumer RA, Sherman SM, Spear PD, Movshon JA (2001) Visual response properties of neurons in the LGN of normally reared and visually deprived macaque monkeys. J Neurophysiol 85:2111-2129.

Marrocco RT, McClurkin JW, Young RA (1982) Spatial summation and conduction latency classification of cells of the lateral geniculate nucleus of macaques. J Neurosci 2:1275-1291.

McMahon MJ, Packer OS, Dacey DM (2004) The classical receptive field surround of primate parasol ganglion cells is mediated primarily by a non-GABAergic pathway. J Neurosci 24:3736-3745.

Packer O, Diller LC, Verweij J, Lee BB, Pokorny J, Williams DR, Dacey DM, Brainard DH (2001) Characterization and use of a digital light projector for vision research. Vision Res 41:427-439.

Passaglia CL, Enroth-Cugell C, Troy JB (2001) Effects of remote stimulation on the mean firing rate of cat retinal ganglion cells. J Neurosci 21:5794-5803.

Passaglia CL, Troy JB, Ruttiger L, Lee BB (2002) Orientation sensitivity of ganglion cells in primate retina. Vision Res 42:683-694.

Peichl L (1991) Alpha ganglion cells in mammalian retinae: Common properties, species differences, and some comments on other ganglion cells. Vis Neurosci 7:155-169.

Peichl L, Wässle H (1979) Size, scatter and coverage of ganglion cell receptive field centers in the cat retina. J Physiol 291:117-141.

Peichl L, Wässle H (1981) Morphological identification of on- and offcentre brisk transient $(\mathrm{Y})$ cells in the cat retina. Proc R Soc Lond B Biol Sci 212:139-156.

Peichl L, Wässle H (1983) The structural correlate of the receptive field centre of alpha ganglion cells in the cat retina. J Physiol 341:309-324. 
Peichl L, Ott H, Boycott BB (1987) Alpha ganglion cells in mammalian retinae. Proc R Soc Lond B Biol Sci 231:169-197.

Perry VH, Cowey A (1981) The morphological correlates of X- and Y-like retinal ganglion cells in the retina of monkeys. Exp Brain Res 43:226-228.

Perry VH, Cowey A (1984) Retinal ganglion cells that project to the superior colliculus and pretectum in the macaque monkey. Neuroscience 12:1125-1137.

Perry VH, Oehler R, Cowey A (1984) Retinal ganglion cells that project to the dorsal lateral geniculate nucleus in the macaque monkey. Neuroscience 12:1101-1123.

Petrusca D, Grivich MI, Sher A, Field GD, Gauthier JL, Greschner M, Shlens J, Chichilnisky EJ, Litke AM (2007) Identification and characterization of a Y-like primate retinal ganglion cell type. J Neurosci 27:11019-11027.

Pokorny J, Smithson H, Quinlan J (2004) Photostimulator allowing independent control of rods and the three cone types. Vis Neurosci 21:263-267.

$\mathrm{Pu}$ M, Berson DM, Pan T (1994) Structure and function of retinal ganglion cells innervating the cat's geniculate wing: an in vitro study. J Neurosci 14:4338-4358.

Rodieck RW, Brening RK (1983) Retinal ganglion cells: properties, types, genera, pathways and trans-species comparisons. Brain Behav Evol 23:121-164.

Rodieck RW, Watanabe M (1993) Survey of the morphology of macaque retinal ganglion cells that project to the pretectum, superior colliculus, and parvicellular laminae of the lateral geniculate nucleus. J Comp Neurol 338:289-303.

Rodieck RW, Brening RK, Watanabe M (1993) The origin of parallel visual pathways. In: Contrast sensitivity (Shapley R, Lam DM-K, eds), pp 117144. Cambridge, MA: MIT.

Roska B, Nemeth E, Orzo L, Werblin FS (2000) Three levels of lateral inhibition: a space-time study of the retina of the tiger salamander. J Neurosci 20:1941-1951.

Rowe MH, Cox JF (1993) Spatial receptive-field structure of cat retinal W cells. Vis Neurosci 10:765-779.

Schiller PH, Malpeli JG (1977) Properties and tectal projections of monkey retinal ganglion cells. J Neurophysiol 40:428-445.

Schiller PH, Malpeli JG (1978) Functional specificity of lateral geniculate nucleus laminae of the rhesus monkey. J Neurophysiol 41:788-797.

Schubert T, Degen J, Willwcke K, Hormuzdi SG, Monyer H, Weiler R (2005) Connexin 36 mediates gap junctional coupling of alpha-ganglion cells in mouse retina. J Comp Neurol 485:191-201.

Shapley R, Perry VH (1986) Cat and monkey retinal ganglion cells and their visual functional roles. Trends Neurosci 9:229-235.

Shapley R, Kaplan E, Soodak R (1981) Spatial summation and contrast sensitivity of $\mathrm{X}$ and $\mathrm{Y}$ cells in the lateral geniculate nucleus of the macaque. Nature 292:543-545.

Sherman SM, Wilson JR, Kaas JH, Webb SV (1976) X- and Y-cells in the dorsal lateral geniculate nucleus of the owl monkey (Aotus trivirgatus). Science 192:475-477.

Silveira LC, Perry VH (1991) The topography of magnocellular projecting ganglion cells (M-ganglion cells) in the primate retina. Neuroscience 40:217-237.

So YT, Shapley R (1981) Spatial tuning of cells in and around lateral geniculate nucleus of the cat: $\mathrm{X}$ and $\mathrm{Y}$ relay cells and periogeniculate interneurons. J Neurophysiol 45:107-120.
Solomon S, Lee B, Sun H (2006) Suppressive surrounds and contrast gain in magnocellular-pathway retinal ganglion cells of macaque. J Neurosci 26:8715-8726.

Spear PD, McCall MA, Tumosa N (1989) W- and Y-cells in the C layers of the cat's lateral geniculate nucleus: Normal properties and effects of monocular deprivation. J Neurophysiol 61 58-73.

Spear PD, Moore RJ, Kim CB, Xue JT, Tumosa N (1994) Effects of aging on the primate visual system: spatial and temporal processing by lateral geniculate neurons in young adult and old rhesus monkeys. J Neurophysiol 72:402-420.

Spitzer H, Hochstein S (1985) Simple- and complex-cell response dependence on stimulation parameters. J Neurophysiol 53:1244-1265.

Stone J (1983) Parallel processing in the visual system: the classification of retinal ganglion cells and its impact on the neurobiology of vision. New York: Plenum.

Swanson WH, Ueno T, Smith VC, Pokorny J (1987) Temporal modulation sensitivity and pulse-detection thresholds for chromatic and luminance perturbations. J Opt Soc Am A 4:1992-2005.

Troy JB, Lee BB (1994) Steady discharges of macaque retinal ganglion cells. Vis Neurosci 11:111-118.

Troy JB, Einstein G, Schuurmans RP, Robson JG, Enroth-Cugell C (1989) Responses to sinusoidal gratings of two types of very nonlinear retinal ganglion cells of cat. Vis Neurosci 3:213-223.

Troy JB, Schweitzer-Tong DE, Enroth-Cugell C (1995) Receptive-field properties of Q retinal ganglion cells of the cat. Vis Neurosci 12:285-300.

Vaney DI (1992) Photochromic intensification of diaminobenzidine reaction product in the presence of tetrazolium salts: applications for intracellular labelling and immunohistochemistry. J Neurosci Methods 44:217-223.

Vaney DI (1994) Patterns of neuronal coupling in the retina. Prog Retin Eye Res 13:301-355.

Victor JD, Shapley RM (1979) The nonlinear pathway of Y ganglion cells in the cat retina. J Gen Physiol 74:671-689.

Völgyi B, Abrams J, Paul DL, Bloomfield SA (2005) Morphology and tracer coupling pattern of alpha ganglion cells in the mouse retina. J Comp Neurol 492:66-77.

Wässle H, Boycott BB, Illing RB (1981) Morphology and mosaic of on- and off-beta cells in the cat retina and some functional considerations. Proc R Soc Lond B Biol Sci 212:177-195.

Watanabe M, Rodieck RW (1989) Parasol and midget ganglion cells of the primate retina. J Comp Neurol 289:434-454.

White AJ, Solomon S, Martin P (2001) Spatial properties of koniocellular cells in the lateral geniculate nucleus of the marmoset Callithrix jacchus. J Physiol 533:519-535.

White AJ, Sun H, Swanson WH, Lee BB (2002) An examination of physiological mechanisms underlying the frequency-doubling illusion. Invest Ophthalmol Vis Sci 43:3590-3599.

Williams DR, Artal P, Navarro R, McMahon MJ, Brainard DH (1996) Offaxis optical quality and retinal sampling in the human eye. Vision Res 36:1103-1114.

Xin DY, Bloomfield SA (1997) Tracer coupling pattern of amacrine and ganglion cells in the rabbit retina. J Comp Neurol 383:512-528.

Zaghloul KA, Manookin MB, Borghuis BG, Boahen K, Demb JB (2007) Functional circuitry for peripheral suppression in mammalian Y-type retinal ganglion cells. J Neurophysiol 97:4327-4340. 